\title{
Domino Michael-Aldol Annulations for the Stereocontrolled Synthesis of Bicyclo[3.3.1]nonane and Bicyclo[3.2.1]octane Derivatives
}

Rossella Promontorio, ${ }^{\mathrm{a}, \mathrm{b}}$ Jean-Alexandre Richard ${ }^{\mathrm{a}}$ and Charles M. Marson* ${ }^{\mathrm{b}}$

\begin{abstract}
${ }^{a}$ Organic Chemistry, Institute of Chemical and Engineering Sciences, (ICES), Agency for Science, Technology and Research (A*STAR), 8 Biomedical Grove, Neuros, \#07-01, Singapore 138665, Singapore.

${ }^{\mathrm{b}}$ Department of Chemistry, University College London, Christopher Ingold Laboratories, 20 Gordon Street, London WC1H OAJ, U.K.
\end{abstract}

\begin{abstract}
Domino Michael-aldol annulation of cycloalkane-1,3-diones with enals affords a general route to 6-hydroxybicyclo[3.3.1]nonane-2,9-diones and 2-hydroxybicyclo[3.2.1]octane6,8-diones, notably in one-pot procedures under convenient conditions. The annulation is shown to be compatible with one or more substituents at six positions of the bicyclo[3.3.1]nonane-2,9-dione scaffold. In some cases, the relative configuration of the product can be controlled by the appropriate choice of solvent, base and temperature for the annulation. In contrast to the chair-chair conformations usually adopted, the bicyclo compounds derived from 2,4,4-trimethylcyclohexane-1,3-dione possessed boat-chair conformations. Oxidation of the annulation products gave the corresponding bicyclo triketones.
\end{abstract}

Keywords: Annulation, domino Michael-aldol addition, bicyclo[3.3.1]nonane, stereocontrolled cyclisation, boat-chair conformers

\section{Introduction}

Alicyclic frameworks often have advantageous pharmaceutical properties compared with substituted aromatic rings, principally by conferring higher aqueous solubility, lower toxicity and greater structural diversity, including stereochemistry.[1,2] Polysubstituted bicyclo compounds (e.g. derivatives of bicyclo[3.3.1]nonane [3] and of bicyclo[3.2.1]octane)[4] have long presented challenges for organic synthesis (Figure 1a), especially in the placement of substituents with stereocontrol, and are become increasingly important in medicinal chemistry.[2,5] In particular, several bicyclo[3.3.1]nonanes of the polyprenylated acylphloroglucinol (PPAP) family (Figure 1b) possess multiple therapeutic effects including anti-bacterial, anti-depressant, anti-viral and anti-cancer properties.[6-8] 
a)

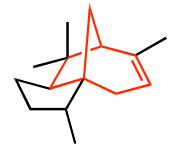

$\alpha$-Cedrene

(Component of cedar oil)



Wickerol A

(Influenza A antiviral agent)<smiles>C=C1CCC2(C)CCCC1C2(C)CO</smiles>

Gymnomitrol

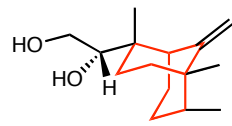

Trifarienol A

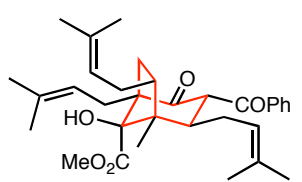

Hypatulin B

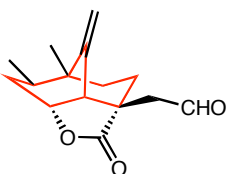

Upial
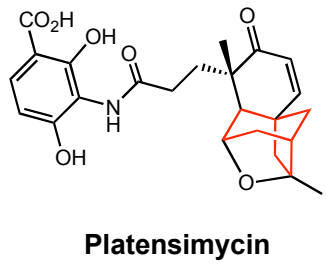
(Antibiotic)

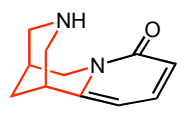

Cytisine

(Ligand for $\alpha 4 \beta 2$ nicotinic acetylcholine receptor)

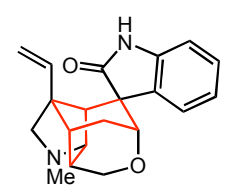

Gelsemine

(Glycine receptor

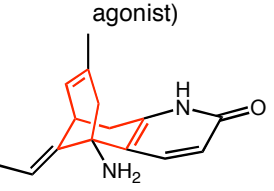

Huperzine A

(Neuroprotective agent)

b)

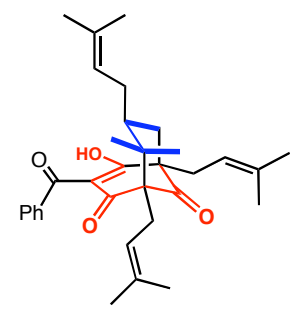

(-)-Clusianone

(Anticancer and anti-HIV agent)

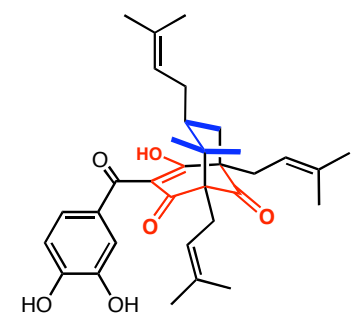

Aristophenone

(Antioxidant and anticancer agent)

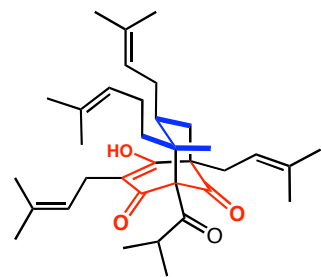

(+)-Hyperforin

(Antidepressant, antibacterial, and antimalarial agent)

Figure 1. (a) Representative natural products featuring bicyclo[3.3.1] and [3.2.1] scaffolds.

(b) Representative polyprenylated acylphloroglucinols with biological activity.

Most synthetic methodology for the construction of bicyclo[3.3.1]nonane derivatives involves a sequential process rather than a domino annulation, an excellent recent example being the alkylation of a disubstituted 1,3-dimethoxybenzene with an enantiomerically pure epibromohydrin followed by Lewis-acid ring opening of the epoxide, effecting an enantioselective desymmetrisation.[9] Subsequent oxidation enabled the Shair group to complete the synthesis of a type A PPAP natural product, (+)-hyperforin.[9] This approach established the utility of derivatives of dihydroresorcinols as key precursors of bicyclo[3.3.1]octane derivatives, with the possibility of later oxidation should a phloroglucinol-derived bicyclo[3.3.1] loctane be required.

Seeking to develop a domino annulation, we had regard to the putative biosynthesis of hyperforin [7,10] and related natural products involving the annulation of a substituted phloroglucinol (Scheme 1, eq. I) by alkylative dearomatisation with a prenyl unit, then a second electrophilic attack completing the annulation. Although to the best of our knowledge a biomimetic synthesis involving both steps is not known, a biomimetic cationic cyclisation (the second step) induced by formic acid afforded a bicyclo system that was converted into (-)clusianone.[11] Regarding domino alkylation-conjugate addition sequences, Porco and coworkers used annulating dielectrophiles comprising various allylic alcohol and 2-alkenal derivatives that contain a leaving group at the 2-position;[12] bicyclo[3.3.1]nonane derivatives of the PPAP type can be obtained, stereocontrol often being possible at the central carbon atom 
of the annulating unit. Porco also achieved domino conjugate addition-alkylation sequences that proceed through a bicyclo[3.3.1]nonane scaffold but which result in adamantanone derivatives.[13] Additionally, the Porco group has developed powerful palladium-catalysed alkylative dearomatisation-annulation domino reactions of 2-acylphloroglucinol derivatives with bisBoc-protected methylenepropane-1,3-diol.[14] A related palladium-catalysed Tsuji-Trost approach had already been demonstrated, as in the reaction of a dihydroresorcinol derivative with the dicarbonate of methylenepropane-1,3-diol (Scheme 1, eq. II).[15] Lastly, a succinct domino approach to the synthesis of substituted bicyclo[3.3.1]nonanes involves annulation by diacylation of a substituted cyclohexanone using malonyl chloride,[16-18] the Effenberger cyclisation (Scheme 1, eq. III). However, the reaction usually proceeds in modest yield and is largely limited to 2-unsubstituted malonyl derivatives and to the annulation of a six-membered ring.
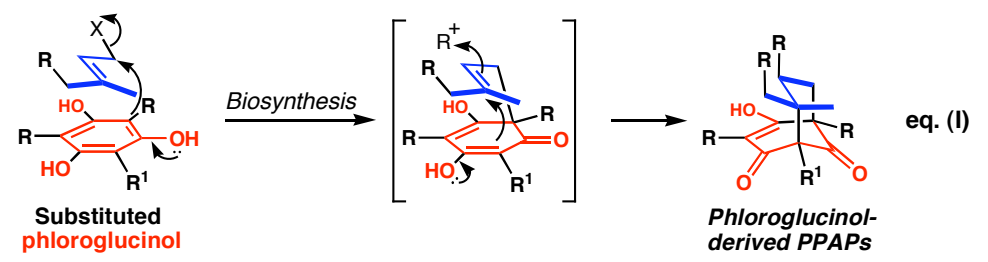

Substituted
phloroglucinol

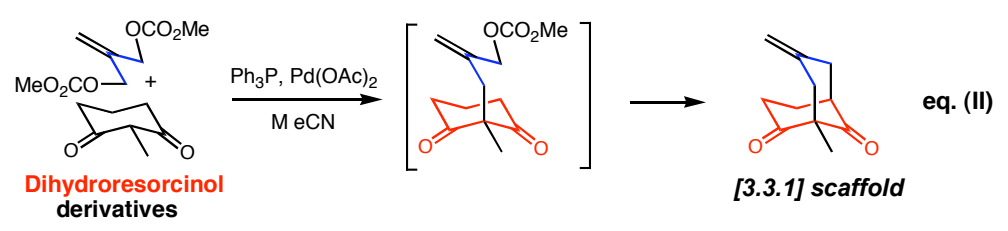

derivatives

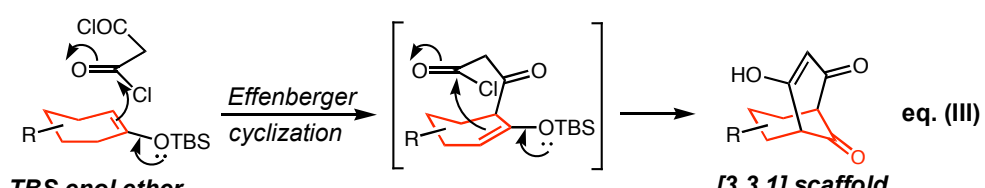

TBS enol ether

[3.3.1] scaffold

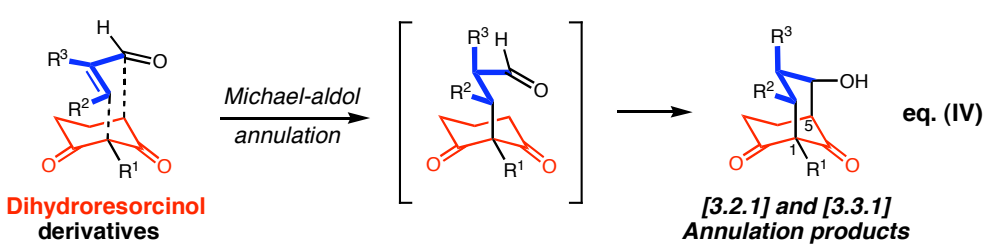

Scheme 1. Biosynthesis of PPAPs, and selected domino annulation strategies for bicyclo systems.

Given the emerging potential of bicyclo scaffolds in medicinal chemistry,[1,2,5] and the limitations of current domino annulations that afford bicyclo systems, a succinct synthetic method was sought for that could generate the maximum number of stereocentres with stereocontrol, with flexibility both in the incorporation of substituents and in the size of the ring undergoing annulation. Having regard to the above criteria of diversity, and inspired by the biosynthetic annulation of phloroglucinol derivatives, we examined the feasibility of domino Michael-aldol annulations of 2-substituted cyclohexane-1,3-diones with enals, a onepot process that can create stereocentres at any of the three carbon atoms in the annulating unit 
(Scheme 1, eq. IV). Here we report the efficacy of this domino annulation, examine its scope, and show that it can afford highly substituted bicyclo[3.2.1]octanes or bicyclo[3.3.1]nonanes, depending on the size of the cycloalkanedione used.

\section{Results and Discussion}

Michael-Aldol annulations have furnished polysubstituted cyclohexanone derivatives, in some cases with high enantioselectivity.[19] However, with few exceptions,[20] a cyclohexanone ring lacking an electron-withdrawing group at the $\alpha$-position has seldom been shown to react with an enone or enal to give a bicyclo ketol. Bicyclo formation has mainly been achieved by reacting $\alpha$-alkoxycarbonyl- or $\alpha$-acyl-cycloalkanones with either aldehydes[21-23] or ketones.[24] One example of an acid-catalysed annulation of a substituted 2acylcyclohexanone was described by Nicolaou,[21] and afforded a 2:1 mixture of diastereoisomers of ketol 1 (Scheme 2, eq. V). The relative configurations were not assigned but are presumably as in Scheme 2, given that oxidation afforded the corresponding trione in $81 \%$ yield, the 3-methyl group being assigned as exo to the bridgehead carbonyl group. Michael-aldol annulation of $\beta$-keto esters has been achieved using $N$-heterocyclic carbene catalysts, but not usually with stereocontrol (e.g. ketol 2 in eq. VI, Scheme 2).[22] Initial formation of the enamine enables the reverse mode of annulation to be achieved, but again with little diastereoselection (e.g. ketol 3 in eq. VII, Scheme 2).[23] The corresponding reaction with methacrolein proceeded with significant stereocontrol (48\% of the 6-endo-hydroxy-7-exomethyl bicyclo ketol) but was conducted over 9 days.[23]
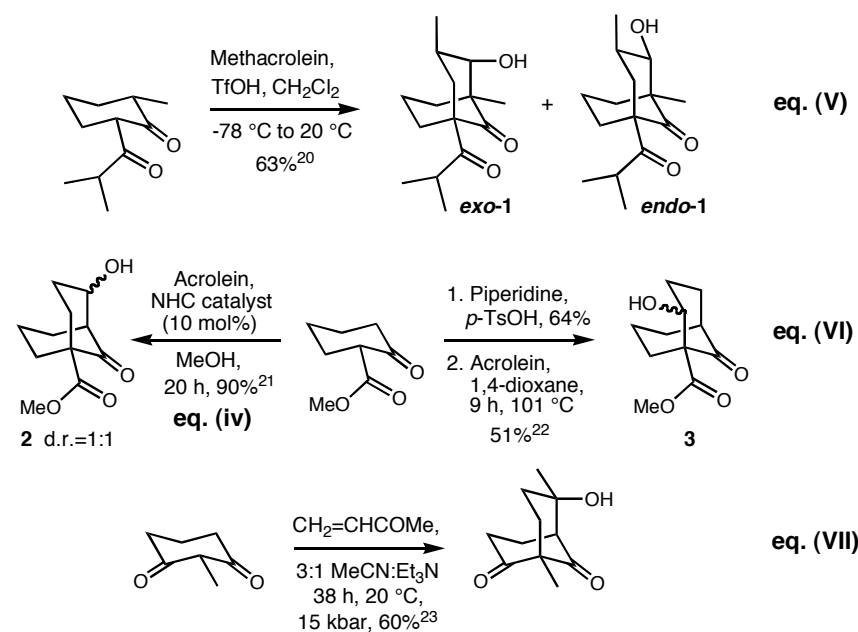

eq. (VII)

Scheme 2. Michael-aldol annulations giving bicyclo ketols.

Given the limitations in scope and/or stereocontrol using $\alpha$-alkoxycarbonyl- or $\alpha$-acylcycloalkanones in such annulation reactions, investigation of cycloalkane-1,3-diones appeared to be a potentially useful alternative to the construction of functionalised bicyclo[3.n.1]alkane scaffolds. However, to the best of our knowledge, the only such annulations involving a cyclohexane-1,3-dione derivative were reported by Dauben, in which enones were reacted at very high pressure to give ketols (Scheme 2, eq. VII).[24] Accordingly, a pilot study of the 
reaction of 2-methylcyclohexane-1,3-dione (4) with acrolein was made (Table 1). Given the literature precedents for the use of secondary and tertiary organic bases (e.g. eq. VI and VII, Scheme 2), including piperidine,[25] a selection of bases was first studied (Table 1, entries 19). No reaction was observed using $\mathrm{NaOMe}$ or pyrrolidine (entries 1 and 2) whereas triethylamine, DIPEA, imidazole or pyridine afforded exclusively the Michael adduct 5 in 62 83\% yield (Table 1, entries 3-6). In contrast to pyridine, DMAP provided the desired 6hydroxybicyclo[3.3.1]nonane-2,9-diones $\mathbf{6}$ in excellent yield and appreciable diastereoselectivity (entry 7). The strong base DBU provided a 1:1 mixture of the Michael adduct 5 and the bicyclo ketols 6 (1:1 carbinol epimers, entry 8), whereas the weaker base 1,4diazabicyclo[2.2.2] octane (DABCO) gave complete conversion into the bicyclo ketols 6 (1:1 carbinol epimers, entry 9). Although 10 mol\% DABCO afforded a mixture of products 5 and $\mathbf{6}$ (entry 10), 20 mol\% DABCO provided exclusively the bicyclo products 6 (100\% conversion, $65 \%$ isolated yield of $1: 1$ epimers, entry 11 ). Under the same conditions, other solvents, including more polar solvents, did not improve the yield of bicyclo compounds 6 (entries 1215). However, at $95{ }^{\circ} \mathrm{C}$ for $16 \mathrm{~h}$ DABCO (20 mol\%) achieved complete conversion into ketols 6 (66:34 epimeric ratio, entry 16). Under the same conditions but heating for longer (48 h) quantitative conversion into a 90:10 ratio of epimers was achieved (entry 17); optimisation of the d.r. (entries 16-18) showed that DABCO (1 equiv.) enabled full conversion solely to the exo-ketol 6 (entry 18). Given the literature precedent for bicyclo compound formation using acidic reagents,[18] the use of $p$-TsOH, TFA, and TfOH were examined but were found to be ineffective (entries 20, 21 and 23), except for $20 \%$ TFA in $\mathrm{MeCN}$ at $95{ }^{\circ} \mathrm{C}$ which afforded $36 \%$ of the ketol 6 (entry 22). Having demonstrated the benefit of heat to the selectivity of the reaction, neutral conditions were then examined; only the exo-ketol 6 was detected, with good to quantitative conversion (entries 24 and 25).

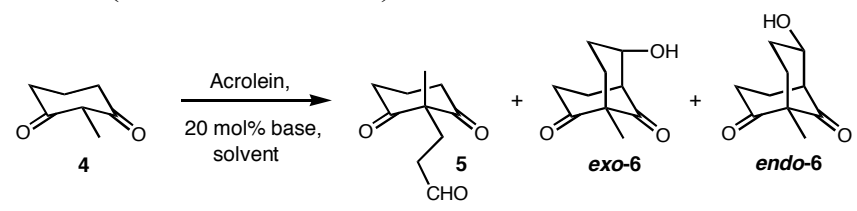

Table 1. Optimisation of bicycloketols from methylcyclohexane-1,3-dione (4) and acrolein., ${ }^{\text {a,b }}$

\begin{tabular}{ccccccc}
\hline Entry & Base/Acid & Solvent & $\mathbf{T}\left({ }^{\circ} \mathbf{C}\right)$ & Time (h) & $\mathbf{5}(\%)$ & Exo-6: Endo-6 (\%) \\
\hline 1 & NaOMe & $\mathrm{MeOH}$ & 25 & 16 & - & - \\
2 & Pyrrolidine (1 eq.) & $\mathrm{MeCN}$ & 25 & 16 & - & - \\
3 & $\mathrm{Et}_{3} \mathrm{~N}(1$ eq. $)$ & $\mathrm{MeCN}$ & 25 & 16 & 62 & - \\
4 & $(i \text {-Pr })_{2} \mathrm{NEt}(1$ eq. $)$ & $\mathrm{MeCN}$ & 25 & 16 & 62 & - \\
5 & Imidazole (1 eq.) & $\mathrm{MeCN}$ & 25 & 16 & 83 & - \\
6 & Pyridine (1 eq.) & $\mathrm{MeCN}$ & 25 & 32 & 83 & - \\
7 & DMAP (1 eq.) & $\mathrm{MeCN}$ & 25 & 16 & traces & $70: 30(95)$ \\
8 & DBU (1 eq. $)$ & $\mathrm{MeCN}$ & 25 & 32 & 50 & $50: 50(50)$ \\
9 & DABCO (1 eq. $)$ & $\mathrm{MeCN}$ & 25 & 16 & - & $50: 50(100)$ \\
\hline
\end{tabular}




\begin{tabular}{|c|c|c|c|c|c|c|}
\hline 10 & DABCO (0.1 eq.) & $\mathrm{MeCN}$ & 25 & 16 & 50 & $50: 50(50)$ \\
\hline 11 & DABCO (0.2 eq.) & $\mathrm{MeCN}$ & 25 & 16 & - & $50: 50(100)$ \\
\hline 12 & DABCO (0.2 eq.) & $\mathrm{EtOH}$ & 25 & 16 & 62 & traces \\
\hline 13 & DABCO (0.2 eq.) & DMF & 25 & 16 & 95 & - \\
\hline 14 & DABCO (0.2 eq.) & DMSO & 25 & 16 & 50 & $50: 50(50)$ \\
\hline 15 & DABCO (0.2 eq.) & THF & 25 & 16 & 7 & 68:32 (93) \\
\hline 16 & DABCO (0.2 eq.) & $\mathrm{MeCN}$ & 95 & 16 & - & $66: 34(100)$ \\
\hline 17 & DABCO (0.2 eq.) & $\mathrm{MeCN}$ & 95 & 48 & - & $90: 10(100)$ \\
\hline 18 & DABCO (1 eq.) & MeCN & 95 & 48 & - & 100:0 (100) \\
\hline 19 & DABCO (0.2 eq.) & $\mathrm{PhMe}$ & 115 & 16 & 7 & $86: 14(93)$ \\
\hline 20 & $p$-TsOH & $\mathrm{CH}_{2} \mathrm{Cl}_{2}$ & 25 & 16 & 62 & - \\
\hline 21 & TFA & $\mathrm{MeCN}$ & 25 & 16 & 80 & - \\
\hline 22 & TFA & $\mathrm{MeCN}$ & 95 & 16 & - & $100: 0(36)$ \\
\hline 23 & TfOH & $\mathrm{CH}_{2} \mathrm{Cl}_{2}$ & -78 to 25 & 16 & - & - \\
\hline 24 & - & MeCN & 95 & 72 & - & $100: 0(70)$ \\
\hline 25 & - & DMF & 135 & 24 & - & 100:0 (100) \\
\hline
\end{tabular}

\footnotetext{
${ }^{a}$ Percentage of conversion was determined from the ${ }^{1} \mathrm{H}$ NMR spectra of the crude products.

${ }^{b}$ Diastereoisomeric ratios (d.r.) were determined from integration values in the ${ }^{1} \mathrm{H}$ NMR spectra of the products after work-up.
}

Although DMF at $130{ }^{\circ} \mathrm{C}$ was optimal for ketols 6 and $\mathbf{1 3}$ (Table 2, entries 1 and 8) in terms of yield and 6-exo-diastereoselectivity, DMF was found to be unsatisfactory for enals other than acrolein. All reactions were initially run using 20 mol\% of (DABCO) but under those conditions only bicyclo ketols $\mathbf{7}$ and $\mathbf{1 0}$ were obtained in satisfactory yields and diastereoselectivity (Table 2, entries 2 and 5). In all other cases, DABCO (1 equiv.) in MeCN gave the best yields and diastereoselectivities, and most reactions were complete within $16 \mathrm{~h}$. For bicyclo[3.3.1]nonane-6-hydroxy-2,9-diones lacking substitution at the 7- and 8-positions the exo-ketols were obtained, either predominantly (entries 2 and 4) or exclusively (entries 1 and 3); that preference was also observed in the bicyclo[3.2.1]octane series (entry 8). In contrast, the 6-endo-ketols predominated in bicyclo compounds that contained an equatorial substituent on the carbon atom (in the bridging unit) adjacent to the alcohol (entry 5) or on the carbon atom remote from the alcohol (entries 9,11 and 12). However, where a 2-prenyl group was present and also either a 7-or 8-substituent, the exo-ketols predominated (entries 6 and 7). 
Table 2. Annulation of substituted cyclohexane-1,3-diones to give bicyclo ketols. ${ }^{a, b}$

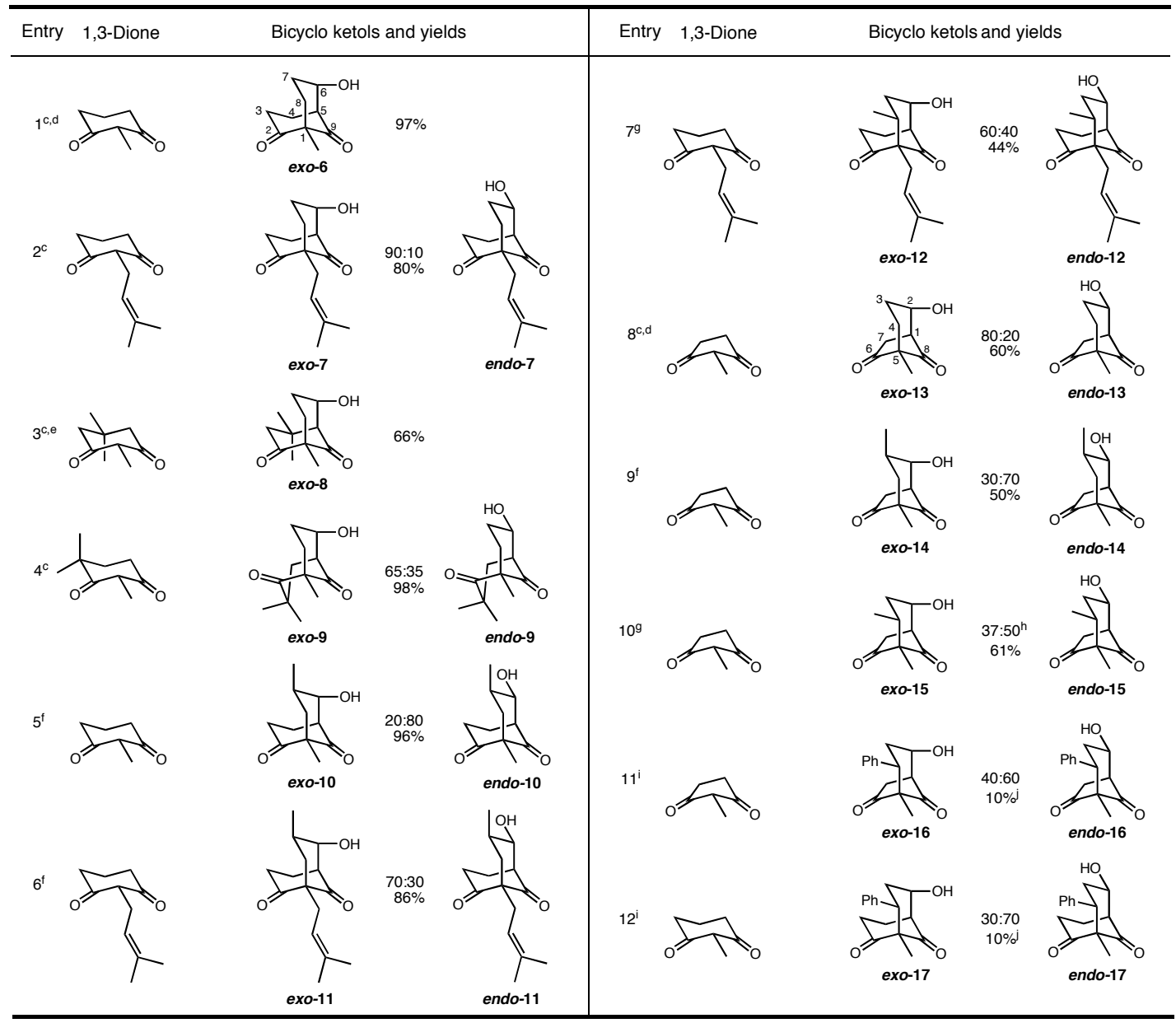

${ }^{\mathrm{a}}$ Reactions performed in the presence of DABCO ( 0.2 equiv or 1.0 equiv.) at $95{ }^{\circ} \mathrm{C} .{ }^{\mathrm{b}}$ Endo and exo refer to the orientation of the hydroxy group. ${ }^{\mathrm{c}}$ Reaction with acrolein. ${ }^{\mathrm{d}}$ Reaction performed in DMF at $135{ }^{\circ} \mathrm{C}$. ${ }^{\mathrm{e}}$ Sequential: the unpurified Michael adduct was isolated and then cyclised. ${ }^{\mathrm{f}}$ Reaction with methacrolein. ${ }^{\mathrm{g}}$ Reaction with crotonaldehyde. ${ }^{\mathrm{h}} 13 \%$ of an additional isomer was detected by ${ }^{1} \mathrm{H}$ NMR spectroscopy. ${ }^{i}$ Reaction with cinnamaldehyde. ${ }^{j}>95 \%$ conversion by ${ }^{1} \mathrm{H}$ NMR spectroscopy; low isolated yield attributed to partial decomposition of $\mathbf{1 6}$ and $\mathbf{1 7}$ during purification.

Assignment of the 6-exo-ketols 6 was indicated by the presence of small coupling constants $(<5 \mathrm{~Hz})$ for the 6-CH(OH) hydrogen atom, in contrast to that the 6-endo-ketols (e.g. transdiaxial $\mathrm{J}_{5,6}=11.5 \mathrm{~Hz}$ for endo-6, and $10.5 \mathrm{~Hz}$ for endo-10). The isolation of endo-ketol $\mathbf{1 0}$, together with its different NMR data from the exo-ketol $\mathbf{1 0}$ (isolated in 6\% yield from a reaction in DMF at $95{ }^{\circ} \mathrm{C}$ ) confirmed the assignments in entry 5 to be a mixture of exo- and endo-diastereoisomers, and excluded the possibility of equilibrating conformers as an explanation of the results. The situation is similar for the various optimisation runs in Table 2 which can only be explained by increasing predominance of exo-ketol 6 at higher temperatures and/or longer reaction times. The NMR data for all the bicyclo ketols comprise a pattern of chemical shifts and coupling constants consistent with the structural assignments given in Table 2. Additional support for the structures assigned by NMR spectroscopy is found in the X-ray crystal structure of the 3,5-dinitrobenzoyl derivative of exo-ketol 6 which shows that the C-O bond in the 6- $\mathrm{CH}(\mathrm{OH})$ moiety is axial; the relatively small couplings of $5.2 \mathrm{~Hz}$ and $1.6 \mathrm{~Hz}$ for 
the equatorial $\mathrm{CH}$-OCOAr hydrogen atom in this ester parallel the small coupling constants observed for exo-versus endo-epimers.

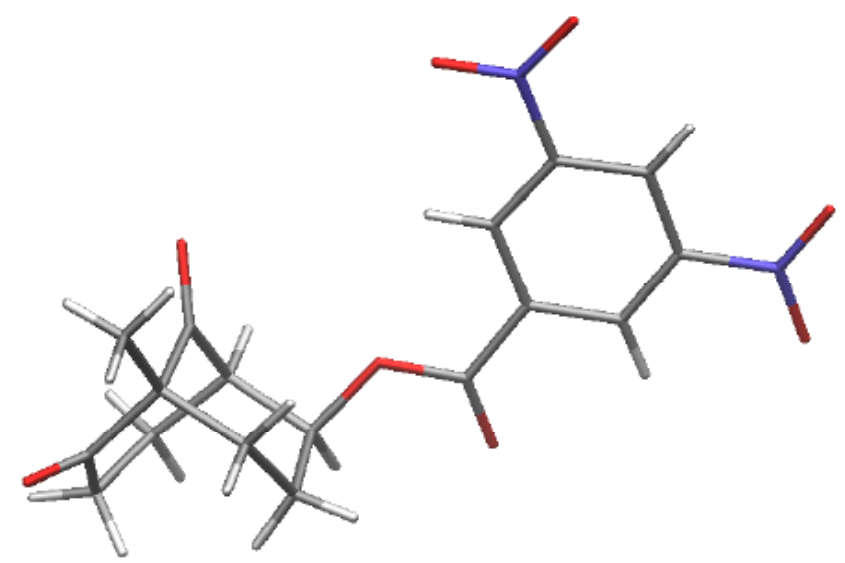

Figure 2. X-ray structure (ORTEP) of the 3,5-dinitrobenzoate ester of exo-ketol 6.[23]

The annulation methodology was also found to be effective using gem-dimethyl-substituted cyclohexane-1,3-diones (Table 2, entries 3 and 4). In the case of 2,4,4-trimethylcyclohexane1,3-dione, reaction with methacrolein and crotonaldehyde afforded the bicyclo ketols $\mathbf{1 8}(65 \%)$ and 19 (49\%) respectively (Scheme 3); simplification of the mixtures of diastereoisomers 18 and 19 was achieved by oxidation with pyridinium chlorochromate (PCC), giving the triketones 20 and 21 respectively. Similarly, oxidation of ketols 6, 9, 10, with PCC afforded the respective triketones 22-24 (Scheme 3).
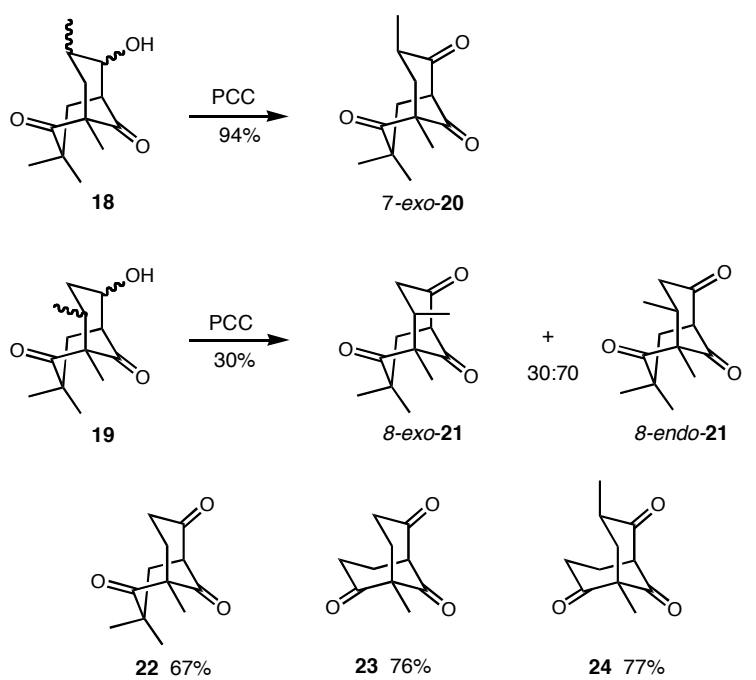

$2376 \%$

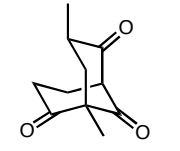

$2477 \%$

Scheme 3. Bicyclo[3.3.1]nonane-2,6,9-triones prepared by the oxidation of ketols with pyridinium chlorochromate.

Molecular models of the gem-dimethyl-substituted trione $\mathbf{2 0}$ indicated that the usual chairchair conformation adopted by most bicyclo[3.3.1]nonanes would suffer severe non-bonding interactions. That inference of an alternative conformation was confirmed by a single-crystal $\mathrm{X}$-ray determination of the trione $\mathbf{2 0}$ which established the unusual boat-chair conformation 
(Fig. 3a). Compared to an $\mathrm{sp}^{3}$ carbon atom, the bridgehead carbonyl group is more able to accommodate a boat structure, and without significant flagpole interactions, for the ring containing the gem-dimethyl group.
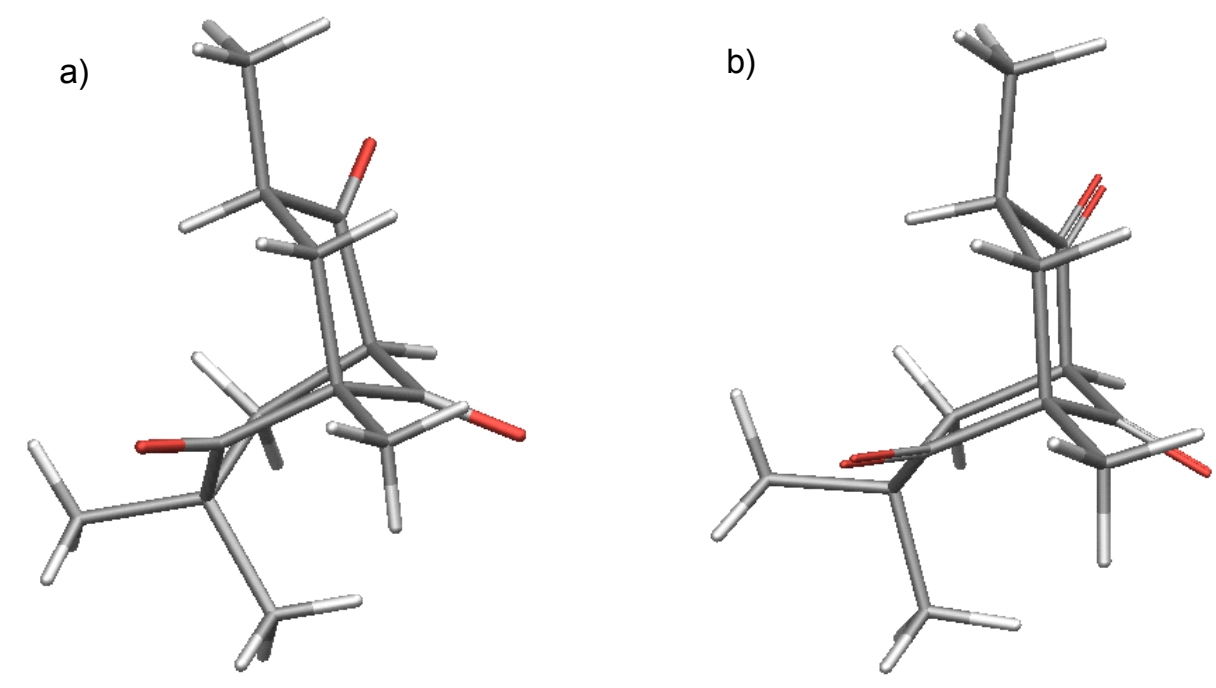

Figure 3. (a) X-ray structure of the trione 20 [26] and (b) lowest energy conformer obtained by OPLS3-GB/SA conformational search.

OPLS3-GB/SA conformational energy searches (Table 3)[27] and quantum mechanics calculations (Tables S1-S3, Supplementary Information) support a boat-chair conformation for the trione 20. In addition, conformational searches on the other bicyclo compounds 21, 22, exo$\mathbf{9}$ and endo-9 that possess the same location of gem-dimethyl-substitution as in $\mathbf{2 0}$ all identified the boat-chair conformation as the lowest in energy (Table 3). Other less favourable chair-boat, twistboat-twistboat and boat-boat conformers could be detected but never the usual chair-chair conformation. The presence of a gem-dimethyl group excludes the chair-chair conformation from being adopted owing to the severe non-bonding interactions of the axial methyl group with the 7-methylene unit that would arise. In contrast, where such a non-bonding interaction is absent, as is the case for triones $\mathbf{2 3}$ and $\mathbf{2 4}$, the usual chair-chair conformation for saturated, substituted bicyclo[3.3.1]nonanes is preferred.

Table 3. Relative conformational energies $\left(\mathrm{kJmol}^{-1}\right)^{\mathrm{a}}$ of $\mathrm{C} 3$-gem-dimethyl-bicyclo compounds in water calculated using OPLS3-GB/SA.[27]

\begin{tabular}{cccccc}
\hline Compound & 7-exo-20 & 8-endo-21 & $\mathbf{2 2}$ & exo-9 & endo-9 \\
\hline Boat-chair $^{\mathrm{b}}$ & 0 & 0 & 0 & 0 & 0 \\
Chair-boat & 16.2 & $-^{\mathrm{c}}$ & 10.0 & 28.4 & 35.6 \\
Twistboat-twistboat & 23.9 & 27.7 & 19.2 & 33.1 & 34.2 \\
Boat-boat & 27.4 & $-^{\mathrm{c}}$ & 21.0 & $-^{\mathrm{c}}$ & $-^{\mathrm{c}}$ \\
Twistboat-twistboat 2 & $-^{\mathrm{c}}$ & $-^{\mathrm{c}}$ & $-^{\mathrm{c}}$ & $-^{\mathrm{c}}$ & 41.3
\end{tabular}


${ }^{\mathrm{a}}$ Energies quoted are relative to the boat-chair conformation. ${ }^{\mathrm{b}}$ The first-named conformer refers to the ring containing the gem-dimethyl group. ${ }^{\mathrm{c}}$ Not found during the conformational search.

Trends in the mode of cyclisation are apparent. For the bicyclo[3.3.1]nonane-2,9-diones, the exo-ketol 6 is generally preferred over the endo-ketol. However, the preference for the exoketol can be overcome by substitution in some locations on the framework, especially for the bicyclo[3.2.1] octane-6,8-diones, as shown in Table 2. Regarding the effect of substitution on the aldehydic chain, an $\alpha$-methyl group derived from methacrolein adopts the equatorial position prior to cyclisation, leading to a significant preference for the endo-alcohol, as seen by comparing entry 1 with entry 5 (Table 2), and entry 8 with entry 9. An $\alpha$-substituent disfavours the formation of the exo-ketol because of three significant and adjacent developing synclinal interactions, compared with only two synclinal interactions for the endo-ketol (Scheme 4). However, a $\beta$-methyl or $\beta$-phenyl group (entries 7 and 10-12) exerts a much weaker effect than an $\alpha$-methyl substituent, although both diminish the strong preference for the exo-isomer that is observed in cases where no $\alpha$ - or $\beta$-substituent is present (Table 2, entries 1,2 and 8).

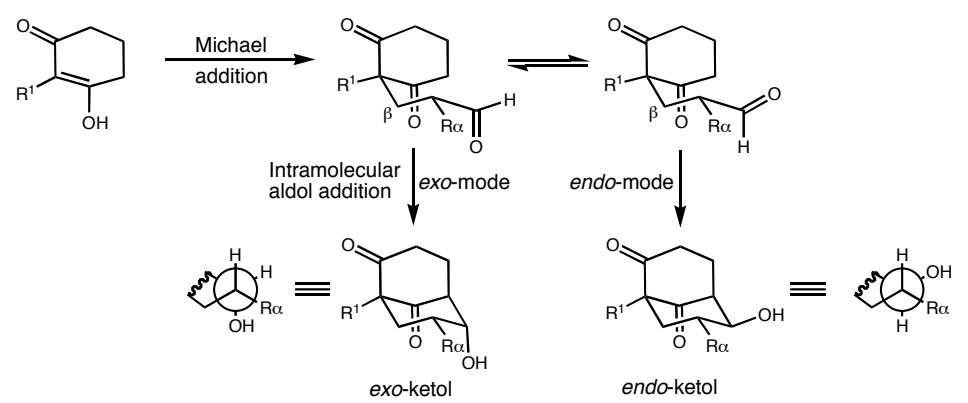

Scheme 4. Modes of cyclisation in the domino Michael-aldol annulation.

Substituents both on the cycloalkane-1,3-dione ring and on the enal can have a profound effect on the conformation on the Michael adduct, and hence on its mode of cyclisation. Thus, only exo-ketol 8 (Table 2, entry 3) was detected, the developing 1,3-diaxial interaction of the $\mathrm{C}=\mathrm{O}$ group with the equatorial methyl group preventing the endo-mode of cyclisation (Scheme 4). In contrast, the location of the gem-dimethyl substituents in entry 4 excludes a chair-chair conformation; consequently, the dione ring adopts a boat conformation, which having smaller non-bonding interactions with the aldehydic carbonyl group leads to a significant amount of the endo-isomer, the preference for the exo-isomer (as shown for $\mathbf{6}$ and 8 ) being eroded. The generally lower selectivities for the cyclopentane-1,3-dione series compared to the cyclohexane-1,3-dione series are also consistent with the flatter and less encumbering cyclopentane-1.3-dione ring that leads to the development of smaller non-bonding interactions during cyclisation.

The formation and conformations of the bicyclo ketols herein studied have implications for the potential of bicyclo compounds in medicinal chemistry. The domino Michael-aldol 
annulation has been shown to be effective with substituents at many locations of the bicyclo framework. Varying degrees of control of the configuration of the hydroxy group in the ketols have been achieved through optimisation of reaction conditions or through the conformational effects exerted by substituents. The bicyclo compounds derived from cycloalkane-1,3-diones often possess well-defined configurations and conformations that can contain multiple substituents with specific directionality that overall achieves a wide coverage of chemical space for a relatively compact structure. Additionally, these non-aromatic alicyclic scaffolds satisfy two important criteria for drug-likeness: high levels of saturation and suitable $\log$ P values.[5]

\section{Conclusions}

The present study has demonstrated the considerable scope of the domino Michael-aldol annulation in obtaining access to 6-hydroxybicyclo[3.3.1]nonane-2,9-diones and 2hydroxybicyclo[3.2.1] octane-6,8-diones from cycloalkane-1,3-diones and enals, notably in onepot procedures under convenient conditions. In some cases, the relative configuration of the annulation product can be controlled by the appropriate choice of solvent, base and temperature. This study has shown that the annulation is compatible with one or more substituents at six positions of the bicyclo[3.3.1]nonane-2,9-dione scaffold. The bicyclo compounds provide structural diversity suitable for use in medicinal chemistry programmes and with potential for use as precursors in natural product synthesis. Oxidation of the annulation products was achieved to give a variety of stable bicyclo triones.

\section{Experimental Section}

General. All moisture-sensitive reactions were performed under an atmosphere of argon and using glassware pre-dried in an oven $\left(100{ }^{\circ} \mathrm{C}\right)$. Thin-layer chromatography was performed on Merck $0.2 \mathrm{~mm}$ aluminium-backed silica gel $60 \mathrm{~F}_{254}$ plates and visualised by UV ( $254 \mathrm{~nm}$ ) or by staining with potassium permanganate with subsequent heating. Flash column chromatography was performed using Merck 0.040-0.063 mm, 230-400 mesh silica gel. Evaporation refers to the removal of solvent under reduced pressure. Melting points were determined using a Büchi B-540 apparatus. Infrared (IR) spectra were recorded on a Perkin-Elmer Spectrum One FT-IR spectrometer; absorptions are quoted in wavenumbers. ${ }^{1} \mathrm{H}$ and ${ }^{13} \mathrm{C}$ NMR spectra were recorded on a Bruker DRX-400 (400 MHz) spectrometer and calibrated using residual undeuterated solvent as an internal reference; chemical shifts are in parts per million ( $\delta$ ) and coupling constants $(J)$ are given in Hertz $(\mathrm{Hz})$. The following abbreviations were used in signal assignments: singlet (s), broad singlet (br s), doublet (d), triplet (t), quartet (q), and multiplet (m). Equivocal assignments are denoted by an asterisk. High-resolution mass spectra (HRMS) were obtained using either an Agilent ESI TOF (time of flight) mass spectrometer at $3500 \mathrm{~V}$ emitter voltage, or using a VG7070H mass spectrometer with Finigan Incos II data system at University College London. 
The following compounds were prepared according to the literature: 2-(3-methylbut-2-en-1yl)cyclohexane-1,3-dione; ${ }^{28} 2,5,5$-trimethyl-1,3-cyclohexanedione. ${ }^{29}$

2,4,4-Trimethylcyclohexane-1,3-dione. To a solution of 4,4-dimethyl-1,3-cyclohexanedione $(5.0 \mathrm{~g}, 35.6 \mathrm{mmol})$ in aqueous sodium hydroxide $(3 \mathrm{M}, 12.5 \mathrm{~mL})$ at $0{ }^{\circ} \mathrm{C}$ was added iodomethane $(4.43 \mathrm{~mL}, 71.3 \mathrm{mmol})$, dropwise over $30 \mathrm{~min}$. The ice-bath was then removed and the mixture heated at $100{ }^{\circ} \mathrm{C}$ for $24 \mathrm{~h}$. After cooling, the mixture was extracted with dichloromethane $(3 \times 30 \mathrm{~mL})$, and the combined organic layers washed with water $(2 \times 20$ $\mathrm{mL}$ ) dried over $\mathrm{MgSO}_{4}$, filtered and evaporated. Flash column chromatography (silica gel, 3:7, ethyl acetate; petroleum ether) of the residue gave 2,4,4-trimethylcyclohexane-1,3-dione $(2.84 \mathrm{~g}, 52 \%)$ as a white solid, stable for several weeks when stored at $-20^{\circ} \mathrm{C}$; IR (film): 3005, 2988, 1711, $1458 \mathrm{~cm}^{-1}$; ${ }^{1} \mathrm{H}$ NMR $\left(400 \mathrm{MHz}, \mathrm{CD}_{3} \mathrm{OD}\right) \delta 2.48(2 \mathrm{H}, \mathrm{t}, J=6.5 \mathrm{~Hz}$, $\left.\mathrm{COCH}_{2}\right), 1.79\left(2 \mathrm{H}, \mathrm{t}, J=6.5 \mathrm{~Hz}, \mathrm{C}\left(\mathrm{CH}_{3}\right)_{2} \mathrm{CH}_{2}\right), 1.63\left(3 \mathrm{H}, \mathrm{s}, 2-\mathrm{CH}_{3}\right), 1.08\left(6 \mathrm{H}, \mathrm{s}, \mathrm{C}\left(\mathrm{CH}_{3}\right)_{2}\right)$; ${ }^{13} \mathrm{C}$ NMR $\left(100 \mathrm{MHz}, \mathrm{CD}_{3} \mathrm{OD}\right) \delta 110.0,40.1,35.8,28.0,25.4,7.7$; HRMS (ESI-TOF) $[\mathrm{M}+\mathrm{H}]^{+}$ $\mathrm{C}_{9} \mathrm{H}_{15} \mathrm{O}_{2}$ calcd. 155.1067, found 155.1065.

6-exo-Hydroxy-1-methylbicyclo[3.3.1]nonane-2,9-dione (6). To a stirred solution of 2methyl-1,3-cyclohexanedione (100 mg, $0.79 \mathrm{mmol})$ in dimethylformamide $(4 \mathrm{~mL})$ was added acrolein $(67 \mathrm{mg}, 81 \mu \mathrm{L}, 1.18 \mathrm{mmol})$ at $25{ }^{\circ} \mathrm{C}$. The solution was then heated at $130{ }^{\circ} \mathrm{C}$ for 24 h. After allowing the mixture to cool the solvent was evaporated. The residue was washed with chloroform ( $2 \times 3 \mathrm{~mL})$ to give exo-ketol 6 (142 mg, 97\%) as an oil; IR (film): 3405, 2936, 1727, 1697, $1454 \mathrm{~cm}^{-1}$; ${ }^{1} \mathrm{H}$ NMR (400 MHz, $\left.\mathrm{CDCl}_{3}\right) \delta 4.35$ (1H, dt, $J=3.1,2.6 \mathrm{~Hz}, 6-$ $\mathrm{CH}), 2.93(1 \mathrm{H}, \mathrm{dm}, J=9.7 \mathrm{~Hz}, 5-\mathrm{CH}), 2.60(1 \mathrm{H}, \mathrm{m}, 3-\mathrm{CHeq}), 2.32(1 \mathrm{H}, \mathrm{dt}, J=16.5,9.5 \mathrm{~Hz}$, 3-CHax), 2.22-2.14 (1 H, m, 4-CHeq), 2.14-2.06 (2H, m, 8- $\left.\mathrm{CH}_{2}\right), 1.84$ (1 H, m, 7-CHeq), 1.74$1.67\left(2 \mathrm{H}, \mathrm{m}, 4-\mathrm{CHax}\right.$ and 7-CHax), $1.15\left(3 \mathrm{H}, \mathrm{s}, \mathrm{CH}_{3}\right) ;{ }^{13} \mathrm{C} \mathrm{NMR}\left(100 \mathrm{MHz}, \mathrm{CDCl}_{3}\right) \delta 211.9$ (9-CO), 211.5 (2-CO), $77.0(6-\mathrm{CH}), 63.2(1-\mathrm{C}), 52.2(5-\mathrm{CH}), 38.2\left(3-\mathrm{CH}_{2}\right), 37.4\left(8-\mathrm{CH}_{2}\right)$, $26.4\left(7-\mathrm{CH}_{2}\right), 18.9\left(4-\mathrm{CH}_{2}\right), 16.7\left(\mathrm{CH}_{3}\right)$; HRMS (ESI-TOF) $[\mathrm{M}+\mathrm{H}]^{+} \mathrm{C}_{10} \mathrm{H}_{15} \mathrm{O}_{3}$ calcd. 183.1016, found 183.1018 .

6-endo-Hydroxy-1-methylbicyclo[3.3.1]nonane-2,9-dione (6). From the above reaction conducted in the presence of DABCO (0.2 equiv) in acetonitrile at $20^{\circ} \mathrm{C}$ was obtained a $1: 1$ mixture of epimers at position-6. For endo-ketol 6: ${ }^{1} \mathrm{H}$ NMR $\left(400 \mathrm{MHz}, \mathrm{CDCl}_{3}\right) \delta 4.10(1 \mathrm{H}$, $\mathrm{dt}, J=11.5,5.0 \mathrm{~Hz}, 6-\mathrm{CH}), 3.10(1 \mathrm{H}, \mathrm{m}, 5-\mathrm{CH}), 2.50-2.45\left(2 \mathrm{H}, \mathrm{m}, 3-\mathrm{CH}_{2}\right), 2.29-2.14(4 \mathrm{H}, \mathrm{m}$, 4-CHeq, 7-CHeq and 8- $\left.\mathrm{CH}_{2}\right), 1.65-1.56(1 \mathrm{H}, \mathrm{m}, 4-\mathrm{CHax}), 1.47-1.38$ (1H, m, 7-CHax), 1.14 (3H, s, $\mathrm{CH}_{3}$ ); ${ }^{13} \mathrm{C}$ NMR (100 MHz, $\mathrm{CDCl}_{3}$ ) $\delta 210.2$ (9-CO), 209.3 (2-CO), 73.2 (6-CH), 61.8 (1-C), $52.5(5-\mathrm{CH}), 38.8\left(3-\mathrm{CH}_{2}\right), 35.6\left(8-\mathrm{CH}_{2}\right), 27.8\left(7-\mathrm{CH}_{2}\right), 16.3\left(4-\mathrm{CH}_{2}\right), 15.0\left(\mathrm{CH}_{3}\right)$.

exo-5-Methyl-6,9-dioxobicyclo[3.3.1]nonan-2-yl 3,5-dinitrobenzoate. To a solution of 6hydroxy-1-methylbicyclo[3.3.1]nonane-2,9-dione $\quad(6) \quad(170 \quad \mathrm{mg}, 0.93 \mathrm{mmol})$ in dry 
dichloromethane were added triethylamine $(2.79 \mathrm{mmol}, 282 \mathrm{mg}, 400 \mu \mathrm{L})$ and 3,5dinitrobenzoyl chloride $(1.02 \mathrm{mmol}, 235 \mathrm{mg})$ at $25{ }^{\circ} \mathrm{C}$. The mixture was then stirred at $25{ }^{\circ} \mathrm{C}$ for $16 \mathrm{~h}$. Water $(20 \mathrm{~mL})$ was then added, and the mixture extracted with dichloromethane $(4 \mathrm{x}$ $20 \mathrm{~mL})$. The combined organic layers were washed with water $(3 \times 10 \mathrm{~mL})$, dried over $\mathrm{MgSO}_{4}$, filtered and evaporated. Flash column chromatography (silica gel, 8:2 dichloromethane: ethyl acetate) of the residue gave exo-5-methyl-6,9dioxobicyclo[3.3.1]nonan-2-yl 3,5-dinitrobenzoate (30 mg, 8\%) IR (film): 2936, 1731, 1704, 1629, 1545, $1050 \mathrm{~cm}^{-1} ;{ }^{1} \mathrm{H}$ NMR $\left(400 \mathrm{MHz}, \mathrm{CDCl}_{3}\right) \delta 9.24(1 \mathrm{H}, \mathrm{t}, J=2.1 \mathrm{~Hz}, 4$-aryl), $9.05(2 \mathrm{H}, \mathrm{d}, J=2.1 \mathrm{~Hz}, 2,6$-aryl), $5.62(1 \mathrm{H}, \mathrm{m}, 2-\mathrm{CH}), 3.21(1 \mathrm{H}, \mathrm{m}, 1-\mathrm{CH}), 2.69$ (1H, ddd, $J$ $=16.5,7.5,4.5 \mathrm{~Hz}, 7-\mathrm{CHeq}), 2.47(1 \mathrm{H}, \mathrm{dt}, J=16.5,9.5 \mathrm{~Hz}, 7-\mathrm{CHax}), 2.39-2.27(2 \mathrm{H}, \mathrm{m}, 3-$ CHeq and 8-CHeq), 2.15-2.02 (3H, m, 3-CHax and 4- $\left.\mathrm{CH}_{2}\right), 1.86(1 \mathrm{H}, \mathrm{m}, 8-\mathrm{CHax}), 1.26(3 \mathrm{H}$, s, $\left.\mathrm{CH}_{3}\right) ;{ }^{13} \mathrm{C}$ NMR (100 MHz, $\mathrm{CDCl}_{3}$ ) $\delta 210.8$ (9-CO), 209.4 (6-CO), 161.6 (COOAr), 148.9 (3,5-aryl), 133.6 (1-aryl), 129.5 (2-aryl), 122.9 (4-aryl), 81.1 (2-CH), 63.2 (5-C), 48.4 (1-CH), $38.1\left(7-\mathrm{CH}_{2}\right), * 37.7\left(4-\mathrm{CH}_{2}\right), * 24.4\left(3-\mathrm{CH}_{2}\right), 18.9\left(8-\mathrm{CH}_{2}\right), 16.8\left(5-\mathrm{CCH}_{3}\right) ; m / z\left(\mathrm{EI}^{+}, \%\right) 395$ (20), $394\left(\mathrm{M}^{+}, 100\right), 364$ (17); HRMS [M+H] ${ }^{+} \mathrm{C}_{17} \mathrm{H}_{17} \mathrm{~N}_{2} \mathrm{O}_{8}$ calcd. 377.0979, found 377.0981.

6-Hydroxy-1-(3-methylbut-2-en-1-yl)bicyclo[3.3.1]nonane-2,9-dione (7). To a solution of 2-(3-methylbut-2-en-1-yl)cyclohexane-1,3-dione (200 mg, $1.1 \mathrm{mmol})$ in dry acetonitrile (12 $\mathrm{mL})$ were added acrolein $(92 \mathrm{mg}, 111 \mu \mathrm{L}, 1.65 \mathrm{mmol})$ and DABCO $(0.22 \mathrm{mmol}, 24 \mathrm{mg})$ at 25 ${ }^{\circ} \mathrm{C}$. The solution was then heated at $95^{\circ} \mathrm{C}$ for $48 \mathrm{~h}$. After allowing to cool, water $(20 \mathrm{~mL})$ was added, and the mixture extracted with dichloromethane $(4 \times 20 \mathrm{~mL})$. The combined organic layers were dried over $\mathrm{MgSO}_{4}$, filtered and evaporated to give 7 (200 mg, 80\%) as a 90:10 mixture of exo-7: endo-7. IR (film): 3416, 2917, 1701, $1450 \mathrm{~cm}^{-1}$; exo-7: ${ }^{1} \mathrm{H}$ NMR (600 MHz, $\left.\mathrm{CDCl}_{3}\right) \delta 5.05\left(1 \mathrm{H}\right.$, tsept., $\left.J=5.0,1.0 \mathrm{~Hz}, 1-\mathrm{CCH}_{2} \mathrm{CH}=\right), 4.34(1 \mathrm{H}, \mathrm{m}, 6-\mathrm{CH}), 2.92(1 \mathrm{H}, \mathrm{dm}$, $J=6.8 \mathrm{~Hz}, 5-\mathrm{CH}), 2.57$ (1H, m, 3-CHeq), 2.40-2.30 (2H, m, 1- $\left.\mathrm{CCH}_{2}\right), 2.25-2.05(5 \mathrm{H}, \mathrm{m}, 3-$ CHax, 4- $\left.\mathrm{CH}_{2}, 8-\mathrm{CH}_{2}\right), 1.80(1 \mathrm{H}, \mathrm{m}, 7-\mathrm{CHeq}), 1.70(1 \mathrm{H}, \mathrm{m}, 7-\mathrm{CHax}), 1.61(3 \mathrm{H}, \mathrm{s}$, $\left.=\mathrm{C}\left(\mathrm{CH}_{3}\right) \mathrm{CH}_{3}\right), 1.59\left(3 \mathrm{H}, \mathrm{s},=\mathrm{C}\left(\mathrm{CH}_{3}\right) \mathrm{CH}_{3}\right) ;{ }^{13} \mathrm{C} \mathrm{NMR}\left(100 \mathrm{MHz}, \mathrm{CDCl}_{3}\right) \delta 212.0$ (9-CO), 212.3 (2-CO), $134.7\left(1-\mathrm{CCH}_{2} \mathrm{CH}=\mathrm{C}\right), 118.7\left(1-\mathrm{CCH}_{2} \mathrm{CH}=\right), 77.2$ (6-CH), 66.5 (1-C), 52.5 (5$\mathrm{CH}), 40.4\left(3-\mathrm{CH}_{2}\right), 36.3\left(8-\mathrm{CH}_{2}\right), 31.0\left(1-\mathrm{CCH}_{2}\right), 26.1\left(7-\mathrm{CH}_{2}\right), 25.8\left(1-\mathrm{C}-\mathrm{cis}-\mathrm{CH}_{3}\right), 18.8$ (4$\left.\mathrm{CH}_{2}\right)$, 17.9 1-C-trans- $\left.\mathrm{CH}_{3}\right)$; endo-7: ${ }^{1} \mathrm{H}$ NMR $\left(400 \mathrm{MHz}, \mathrm{CDCl}_{3}\right) \delta 5.05(1 \mathrm{H}, \mathrm{m}, 1-$ $\left.\mathrm{CCH}_{2} \mathrm{CH}=\right), 4.06(1 \mathrm{H}, \mathrm{dt}, J=11.5,4.9 \mathrm{~Hz}, 6-\mathrm{CH}), 3.11(1 \mathrm{H}, \mathrm{m}, 5-\mathrm{CH}), 2.55(1 \mathrm{H}, \mathrm{m}, 3-$ CHeq), 2.40-2.30 (2H, m, 1- $\left.\mathrm{CCH}_{2}\right), 2.26-2.15\left(3 \mathrm{H}, \mathrm{m}, 3-\mathrm{CHax}, 4-\mathrm{CH}_{2}\right), 2.11-2.05(2 \mathrm{H}, \mathrm{m}, 8-$ $\left.\mathrm{CH}_{2}\right), 1.80(1 \mathrm{H}, \mathrm{m}, 7-\mathrm{CHeq}), 1.70(1 \mathrm{H}, \mathrm{m}, 7-\mathrm{CHax}), 1.58\left(6 \mathrm{H}, \mathrm{m},=\mathrm{C}\left(\mathrm{CH}_{3}\right) \mathrm{CH}_{3}\right) ;{ }^{13} \mathrm{C} \mathrm{NMR}$ $\left(150 \mathrm{MHz}, \mathrm{CDCl}_{3}\right) \delta 212.3$ (9-CO), 210.3 (2-CO), $135.0 \quad\left(1-\mathrm{CCH}_{2} \mathrm{CH}=C\right), 118.6$ (1$\left.\mathrm{CCH}_{2} \mathrm{CH}=\right), 73.7(6-\mathrm{CH}), 65.2(1-\mathrm{C}), 52.8(5-\mathrm{CH}), 40.6\left(3-\mathrm{CH}_{2}\right), 34.2\left(8-\mathrm{CH}_{2}\right), 30.6(1-$ $\left.\mathrm{CCH}_{2}\right), 27.2\left(7-\mathrm{CH}_{2}\right), 26.1$ (1-C-cis- $\left.\mathrm{CH}_{3}\right), 18.8\left(4-\mathrm{CH}_{2}\right), 14.6$ (1-C-trans- $\left.\mathrm{CH}_{3}\right)$. HRMS (ESITOF) $[\mathrm{M}+\mathrm{H}]^{+} \mathrm{C}_{14} \mathrm{H}_{21} \mathrm{O}_{3}$ calcd. 237.1485, found 237.1481. 
6-exo-Hydroxy-1,4,4-trimethylbicyclo[3.3.1]nonane-2,9-dione (8). To a stirred solution of 2,5,5-trimethyl-1,3-cyclohexanedione $(1.0 \mathrm{~g}, 6.5 \mathrm{mmol})$ in dry acetonitrile $(25 \mathrm{~mL})$ were added acrolein $(0.65 \mathrm{~mL}, 9.72 \mathrm{mmol})$ and DABCO $(145 \mathrm{mg}, 1.3 \mathrm{mmol})$ at $25{ }^{\circ} \mathrm{C}$. The mixture was heated at $95^{\circ} \mathrm{C}$ for $4 \mathrm{~h}$. After allowing to cool, the residue was dissolved in dry DMF (20 $\mathrm{mL}$ ) and the mixture heated at $135{ }^{\circ} \mathrm{C}$ for $24 \mathrm{~h}$. After allowing to cool, the solvent was evaporated and the residue was washed with chloroform $(2 \times 5 \mathrm{~mL})$ to give ketol $8(0.90 \mathrm{~g}$, $66 \%$ over 2 steps, single diastereoisomer) as an oil: IR (film): 3455, 2958, 1728, $1694 \mathrm{~cm}^{-1}$; ${ }^{1} \mathrm{H}$ NMR (400 MHz, $\mathrm{CDCl}_{3}$ ) $\delta 4.65$ (1H, m, 6-CH), 2.72 (1H, d, $\left.J=18.0 \mathrm{~Hz}, 3-\mathrm{CHeq}\right), 2.49$ (1H, m, 5-CH), 2.45 (1H, dd, $J=18.0 \mathrm{~Hz}, 3-\mathrm{CHax}), 2.26-2.09$ (2H, m, 7-CHeq and 8-CHeq), 2.00-1.82 (2H, m, 7-CHeq and 8-CHeq), $1.22\left(3 \mathrm{H}, \mathrm{s}, 4-\mathrm{C}\left(\mathrm{CH}_{3}\right) \mathrm{CH}_{3}\right), 1.17\left(3 \mathrm{H}, \mathrm{s}, 1-\mathrm{CCH}_{3}\right)$, $0.91\left(3 \mathrm{H}, \mathrm{s}, 4-\mathrm{C}\left(\mathrm{CH}_{3}\right) \mathrm{CH}_{3}\right) ;{ }^{13} \mathrm{C} \mathrm{NMR}\left(100 \mathrm{MHz}, \mathrm{CDCl}_{3}\right) \delta 210.5$ (9-CO) 209.2 (2-CO), 73.4 (6-CH), 65.3 (5-CH), 64.3 (1-C), $52.6\left(3-\mathrm{CH}_{2}\right), 37.5\left(8-\mathrm{CH}_{2}\right), 31.6$ (4-C), 31.1 (4- $\left.\mathrm{CCH}_{3} \mathrm{eq}\right)$, $28.1\left(7-\mathrm{CH}_{2}\right), 27.4\left(4-\mathrm{CCH}_{3} \mathrm{ax}\right), 16.2\left(1-\mathrm{CCH}_{3}\right)$. HRMS (ESI-TOF) $[\mathrm{M}+\mathrm{H}]^{+} \mathrm{C}_{12} \mathrm{H}_{19} \mathrm{O}_{3}$ calcd. 211.1329, found 211.1338 .

6-Hydroxy-1,3,3-trimethylbicyclo[3.3.1]nonane-2,9-dione (9). To a solution of 2,4,4trimethylcyclohexane-1,3-dione (200 $\mathrm{mg}, 1.28 \mathrm{mmol})$ in dry acetonitrile $(12 \mathrm{~mL})$ were added acrolein $(106 \mathrm{mg}, 128 \mu \mathrm{L}, 1.98 \mathrm{mmol})$ and DABCO $(144 \mathrm{mg}, 1.28 \mathrm{mmol})$ at $25{ }^{\circ} \mathrm{C}$. The solution was heated at $95{ }^{\circ} \mathrm{C}$ for $16 \mathrm{~h}$. After allowing to cool, water $(20 \mathrm{~mL})$ was added. The mixture was extracted with dichloromethane $(3 \times 20 \mathrm{~mL})$ and the combined organic layers washed three times with water, dried over $\mathrm{MgSO}_{4}$, filtered and evaporated to give ketol 9 (264 mg, 98\%), as a 65:35 mixture of exo-9: endo-9, IR (film): 3417, 2936, 1729, 1697, 1469 $\mathrm{cm}^{-1}$. Column chromatography (silica gel, 4:6 ethyl acetate: dichloromethane) afforded $\boldsymbol{e x \boldsymbol { o } - 9}$ : ${ }^{1} \mathrm{H} \mathrm{NMR}\left(400 \mathrm{MHz}, \mathrm{CDCl}_{3}\right) \delta 4.26$ (1H, dq, J = 4.5, $\left.2.4 \mathrm{~Hz}, 6-\mathrm{CH}\right), 2.95$ (1H, m, 5-CH), 2.20 (1H, m, 8-CHeq), 2.12-2.00 (2H, m, 4-CHeq and 8-CHax), 1.70-1.65 (2H, m, 7-CH $), 1.48$ $(1 \mathrm{H}, \mathrm{dm}, J=14.4 \mathrm{~Hz}, 4-\mathrm{CHax}), 1.19\left(3 \mathrm{H}, \mathrm{s}, 1-\mathrm{CCH}_{3}\right),{ }^{*} 1.15\left(3 \mathrm{H}, \mathrm{s}, 3-\mathrm{C}\left(\mathrm{CH}_{3}\right) \mathrm{CH}_{3}\right),{ }^{*} 0.97$ (3H, s, 3-C $\left.\left(\mathrm{CH}_{3}\right) \mathrm{CH}_{3}\right) ;{ }^{13} \mathrm{C}$ NMR (100 MHz, $\mathrm{CDCl}_{3}$ ) $\delta 216.2$ (2-CO), 213.7 (9-CO), 78.1 (6$\mathrm{CH}), 60.4(1-\mathrm{C}), 51.9(5-\mathrm{CH}), 45.8(3-\mathrm{C}), 39.4\left(8-\mathrm{CH}_{2}\right), 35.5\left(4-\mathrm{CH}_{2}\right), 26.1\left(3-\mathrm{CCH}_{3} \mathrm{eq}\right), 25.6$ (7- $\left.\mathrm{CH}_{2}\right), 24.6\left(3-\mathrm{CCH}_{3} \mathrm{ax}\right), 18.7\left(1-\mathrm{CCH}_{3}\right)$ and endo-9: ${ }^{1} \mathrm{H}$ NMR $\left(400 \mathrm{MHz}, \mathrm{CDCl}_{3}\right) \delta 4.02$ $(1 \mathrm{H}, \mathrm{dt}, J=11.0,4.5 \mathrm{~Hz}, 6-\mathrm{CH}), 3.15(1 \mathrm{H}, \mathrm{m}, 5-\mathrm{CH}), 2.17(1 \mathrm{H}, \mathrm{dm}, 8-\mathrm{CHeq}), 2.05(1 \mathrm{H}, \mathrm{dd}=$ $J$ 14.7, 2.0 Hz, 4-CHeq), 1.80-1.70 (2H, m, 4-CHax and 7-CHeq), 1.41-1.26 (2H, m, 7-CHax

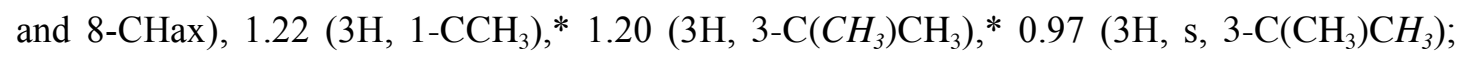
${ }^{13} \mathrm{C} \mathrm{NMR}\left(100 \mathrm{MHz}, \mathrm{CDCl}_{3}\right.$ ) $\delta 216.1$ (2-CO), 211.9 (9-CO), 74.3 (6-CH), 58.9 (1-C), 52.5 (5$\mathrm{CH}), 45.7$ (3-C), $37.0\left(8-\mathrm{CH}_{2}\right), 30.9\left(4-\mathrm{CH}_{2}\right), 27.1 \quad\left(7-\mathrm{CH}_{2}\right), 26.0 \quad\left(3-\mathrm{CCH}_{3} \mathrm{eq}\right), 24.1$ (3$\mathrm{CCH}_{3} \mathrm{ax}$ ), $18.3\left(1-\mathrm{CCH}_{3}\right)$. HRMS (ESI-TOF) $[\mathrm{M}+\mathrm{H}]^{+} \mathrm{C}_{12} \mathrm{H}_{19} \mathrm{O}_{3}$ calcd. 211.1329, found 211.1333 .

6-Hydroxy-1,7-dimethylbicyclo[3.3.1]nonane-2,9-dione (10). To a solution of 2-methyl1,3-cyclohexanedione $(100 \mathrm{mg}, 0.79 \mathrm{mmol})$ in acetonitrile $(6 \mathrm{~mL})$ were added methacrolein 
(84 mg, $98 \mu \mathrm{L}, 1.19 \mathrm{mmol})$ and DABCO $(18 \mathrm{mg}, 0.16 \mathrm{mmol})$ at $25{ }^{\circ} \mathrm{C}$. The solution was heated at $95{ }^{\circ} \mathrm{C}$ for $16 \mathrm{~h}$. After allowing to cool, water $(5 \mathrm{~mL})$ was added and the mixture extracted with dichloromethane $(3 \mathrm{x} 10 \mathrm{~mL})$. The combined organic layers were dried over $\mathrm{MgSO}_{4}$, filtered and evaporated to give ketol $10(150 \mathrm{mg}, 96 \%)$ as an 80:20 mixture of endo10: exo-10: IR (film): 3455, 2936, 1728, $1697 \mathrm{~cm}^{-1}$. Column chromatography (silica gel, 40:60 ethyl acetate:dichloromethane) gave endo-10: ${ }^{1} \mathrm{H} \mathrm{NMR}\left(400 \mathrm{MHz}, \mathrm{CDCl}_{3}\right) \delta 3.62(1 \mathrm{H}$, $\mathrm{dd}, J=10.5,4.8 \mathrm{~Hz}, 6-\mathrm{CH}), 3.08(1 \mathrm{H}, \mathrm{ddd}, J=8.9,4.8,2.1 \mathrm{~Hz}, 5-\mathrm{CH}), 2.64(1 \mathrm{H}, \mathrm{m}, 3-$ CHeq), 2.37 (1H, m, 3-CHax), $2.24(1 \mathrm{H}, \mathrm{m}, 4-\mathrm{CHeq}), 2.12-2.00(2 \mathrm{H}, \mathrm{m}, 7-\mathrm{CH}$ and 8-CHeq), $1.92(1 \mathrm{H}, \mathrm{m}, 8-\mathrm{CHax}), 1.77(1 \mathrm{H}, \mathrm{m}, 4-\mathrm{CHax}), 1.13\left(3 \mathrm{H}, \mathrm{s}, 1-\mathrm{CCH}_{3}\right), 1.02(3 \mathrm{H}, \mathrm{d}, J=6.3 \mathrm{~Hz}$, 7-CHCH$\left.)_{3}\right){ }^{13} \mathrm{C}$ NMR (100 MHz, $\mathrm{CDCl}_{3}$ ) 212.0 (9-CO), 209.9 (2-CO), 78.4 (6-CH), 62.9 (1C), $52.0(5-\mathrm{CH}), 44.4\left(8-\mathrm{CH}_{2}\right), 38.4\left(3-\mathrm{CH}_{2}\right), 32.7(7-\mathrm{CH}), 17.7\left(4-\mathrm{CH}_{2}\right), 16.2\left(1-\mathrm{CCH}_{3}\right)$, $15.5\left(7-\mathrm{CCH}_{3}\right) *$; exo-10: ${ }^{1} \mathrm{H}$ NMR $\left(400 \mathrm{MHz}, \mathrm{CDCl}_{3}\right) \delta 3.96(1 \mathrm{H}, \mathrm{m}, 6-\mathrm{CH}), 2.96$ (1H, ddd, $J$ $=10.2,4.2,2 \mathrm{~Hz}, 5-\mathrm{CH}), 2.62(1 \mathrm{H}, \mathrm{ddd}, J=16.2,7.4,3.4 \mathrm{~Hz}, 3-\mathrm{CHeq}), 2.34(1 \mathrm{H}, \mathrm{m}, 3-$ CHax), $2.20(1 \mathrm{H}, \mathrm{m}, 4-\mathrm{CHeq}), 2.10(1 \mathrm{H}, \mathrm{m}, 7-\mathrm{CH}), 2.01(1 \mathrm{H}, \mathrm{m}, 8-\mathrm{CHeq}), 1.82(1 \mathrm{H}, \mathrm{dd}, J=$ 12.9, $4.5 \mathrm{~Hz}, 8-\mathrm{CHax}), 1.70(1 \mathrm{H}, \mathrm{m}, 4-\mathrm{CHax}), 1.14\left(3 \mathrm{H}, \mathrm{s}, 1-\mathrm{CCH}_{3}\right), 1.00(3 \mathrm{H}, \mathrm{d}, J=6.6 \mathrm{~Hz}$, 7-CHCH$\left.{ }_{3}\right) ;{ }^{13} \mathrm{C} \mathrm{NMR}\left(100 \mathrm{MHz}, \mathrm{CDCl}_{3}\right.$ ) ठ 212.5 (9-CO), 211.8 (2-CO), 80.4 (6-CH), 62.5 (1-C), $52.1(5-\mathrm{CH}), 44.5\left(8-\mathrm{CH}_{2}\right), 38.4\left(3-\mathrm{CH}_{2}\right), 29.9(7-\mathrm{CH}), 18.6\left(4-\mathrm{CH}_{2}\right), 16.8\left(1-\mathrm{CHCH}_{3}\right)$, $16.7\left(7-\mathrm{CCH}_{3}\right)$. HRMS (ESI-TOF) $[\mathrm{M}+\mathrm{H}]^{+} \mathrm{C}_{11} \mathrm{H}_{17} \mathrm{O}_{3}$ calcd. 197.1172, found 197.1170.

6-Hydroxy-7-methyl-1-(3-methylbut-2-en-1-yl)bicyclo[3.3.1]nonane-2,9-dione (11). To a solution of 2-(3-methylbut-2-en-1-yl)cyclohexane-1,3-dione (100 mg, $0.55 \mathrm{mmol}$.) in dry acetonitrile $(6 \mathrm{~mL})$ were added methacrolein $(57.8 \mathrm{mg}, 68 \mu \mathrm{L}, 0.82 \mathrm{mmol})$ and DABCO $(0.55$ mmol, $62 \mathrm{mg}$ ) at $25{ }^{\circ} \mathrm{C}$. The solution was heated at $95{ }^{\circ} \mathrm{C}$ for $16 \mathrm{~h}$. After allowing to cool, water $(10 \mathrm{~mL})$ was added and the mixture was extracted with dichloromethane $(4 \mathrm{x} 10 \mathrm{~mL})$. The combined organic layers were dried over $\mathrm{MgSO}_{4}$, filtered and evaporated to give ketol 11 (118 mg, 86\%) as a 70:30 mixture of exo-11: endo-11; IR (film): 3416, 2918, 1700, $1456 \mathrm{~cm}^{-}$ '; exo-11: ${ }^{1} \mathrm{H}$ NMR (600 MHz, $\left.\mathrm{CDCl}_{3}\right) \delta 5.05\left(1 \mathrm{H}, \mathrm{m}, 1-\mathrm{CCH}_{2} \mathrm{CH}=\right), 3.98(1 \mathrm{H}, \mathrm{m}, 6-\mathrm{CH})$, $2.92(1 \mathrm{H}, \mathrm{m}, 5-\mathrm{CH}), 2.62-2.51\left(1 \mathrm{H}, \mathrm{m}, 3-\mathrm{CH}\right.$ eq), 2.39-2.27 (3H, m, 1-C-CH $\mathrm{CH}_{2}$ and 3-CHax), 2.24-2.13 (m, 2H, 4-CH $\mathrm{CH}_{2}, 1.98(1 \mathrm{H}, \mathrm{m}, 7-\mathrm{CH}), 1.97-1.74\left(2 \mathrm{H}, \mathrm{m}, 8-\mathrm{CH}_{2}\right), 1.61(3 \mathrm{H}, \mathrm{s}, 1-\mathrm{C}-$ cis- $\left.\mathrm{CH}_{3}\right), 1.58\left(3 \mathrm{H}, \mathrm{s}, 1-\mathrm{C}-\right.$ trans- $\left.\mathrm{CH}_{3}\right), 0.97\left(3 \mathrm{H}, \mathrm{d}, J=7.0 \mathrm{~Hz}, 7-\mathrm{CHCH}_{3}\right) ;{ }^{13} \mathrm{C} \mathrm{NMR}(150$ $\left.\mathrm{MHz}, \mathrm{CDCl}_{3}\right) 212.4$ (9-CO), 210.3 (2-CO), $134.8\left(1-\mathrm{CCH}_{2} \mathrm{CH}=\mathrm{C}\right), 118.6\left(1-\mathrm{CCH}_{2} \mathrm{CH}=\right), 80.6$ (6-CH), 65.8 (1-C), $52.2(5-\mathrm{CH}), 43.3\left(8-\mathrm{CH}_{2}\right), 40.5\left(3-\mathrm{CH}_{2}\right), 31.0\left(1-\mathrm{C}-\mathrm{CH}_{2}\right), 29.4(7-\mathrm{CH})$, 26.0 (1-C-cis- $\left.\mathrm{CH}_{3}\right), 18.5\left(4-\mathrm{CH}_{2}\right), 17.9$ (1-C-trans- $\left.\mathrm{CH}_{3}\right), 16.6\left(7-\mathrm{CHCH}_{3}\right)$; endo-11: ${ }^{1} \mathrm{H} \mathrm{NMR}$ $\left(600 \mathrm{MHz}, \mathrm{CDCl}_{3}\right) \delta 5.05\left(1 \mathrm{H}, \mathrm{m}, 1-\mathrm{CCH}_{2} \mathrm{CH}=\right), 3.55(1 \mathrm{H}, \mathrm{dd}, J=7.0,4.8 \mathrm{~Hz}, 6-\mathrm{CH}), 3.07$ $(1 \mathrm{H}, \mathrm{ddd}, J=6.52,3.2,1.4 \mathrm{~Hz}, 5-\mathrm{CH}), 2.62-2.51\left(2 \mathrm{H}, \mathrm{m}, 3-\mathrm{CH}_{2}\right), 2.39-2.27(2 \mathrm{H}, \mathrm{m}, 1-$ $\left.\mathrm{CCH}_{2}\right), 2.13-2.06\left(2 \mathrm{H}, \mathrm{m}, 4-\mathrm{CH}_{2}\right), 1.98(1 \mathrm{H}, \mathrm{m}, 7-\mathrm{CH}), 1.87-1.74\left(2 \mathrm{H}, \mathrm{m}, 8-\mathrm{CH}_{2}\right), 1.65(3 \mathrm{H}$, s, 1-C-cis- $\left.\mathrm{CH}_{3}\right), 1.60\left(3 \mathrm{H}, \mathrm{s}, 1-\mathrm{C}-\right.$ trans- $\left.\mathrm{CH}_{3}\right), 1.00\left(3 \mathrm{H}, \mathrm{d}, J=7.0 \mathrm{~Hz}, 7-\mathrm{CHCH}_{3}\right) ;{ }^{13} \mathrm{C} \mathrm{NMR}$ $\left(150 \mathrm{MHz}, \mathrm{CDCl}_{3}\right)$ ठ 212.7 (9-CO), 212.5 (2-CO), $135.0 \quad\left(1-\mathrm{CCH}_{2} \mathrm{CH}=C\right), 118.5$ (1$\left.\mathrm{CCH}_{2} \mathrm{CH}=\right), 78.8(6-\mathrm{CH}), 66.1(1-\mathrm{C}), 52.2(5-\mathrm{CH}), 43.0\left(8-\mathrm{CH}_{2}\right), 40.3\left(3-\mathrm{CH}_{2}\right), 32.1(7-\mathrm{CH})$, 
$30.6\left(1-\mathrm{CCH}_{2}\right), 26.0\left(1-\mathrm{C}-\right.$ cis- $\left.\mathrm{CH}_{3}\right), 17.6$ (1-C-trans- $\left.\mathrm{CH}_{3}\right), 16.6\left(7-\mathrm{CHCH}_{3}\right), 15.1\left(4-\mathrm{CH}_{2}\right)$; HRMS (ESI-TOF) $[\mathrm{M}+\mathrm{H}]^{+} \mathrm{C}_{15} \mathrm{H}_{23} \mathrm{O}_{3}$ calcd. 251.1642, found 251.1639.

6-Hydroxy-8-methyl-1-(3-methylbut-2-en-1-yl)bicyclo[3.3.1]nonane-2,9-dione (12). To a solution of 2-(3-methylbut-2-en-1-yl)cyclohexane-1,3-dione (100 mg, $0.55 \mathrm{mmol})$ in dry acetonitrile $(6 \mathrm{~mL})$ were added crotonaldehyde $(57 \mathrm{mg}, 68 \mu \mathrm{L}, 0.82 \mathrm{mmol})$ and DABCO (62 $\mathrm{mg}, 0.55 \mathrm{mmol}$ ) at $25{ }^{\circ} \mathrm{C}$. The solution was heated at $95{ }^{\circ} \mathrm{C}$ for $60 \mathrm{~h}$. After allowing to cool, water $(10 \mathrm{~mL})$ was added, and the mixture was extracted with dichloromethane $(4 \times 10 \mathrm{~mL})$. The combined organic layers were dried over $\mathrm{MgSO}_{4}$, filtered and evaporated. Column chromatography (silica gel, 2:8 ethyl acetate:dichloromethane) of the residue gave ketol 12 (61 mg, 44\%) as 60:40 mixture of exo-12: endo-12; IR (film): 3432, 2971, 2992, 1728, 1697 $\mathrm{cm}^{-1}$. Repeated column chromatography of a small fraction enabled the exo-isomer to be isolated, and hence NMR data for the endo-isomer to be deduced: exo-12; ${ }^{1} \mathrm{H}$ NMR (400 $\left.\mathrm{MHz}, \mathrm{CDCl}_{3}\right) \delta 5.06\left(1 \mathrm{H}\right.$, tsept., $\left.J=7.1,1.4 \mathrm{~Hz}, 1-\mathrm{CCH}_{2} \mathrm{CH}=\right), 4.27(1 \mathrm{H}, \mathrm{dt}, J=3.0,2.5 \mathrm{~Hz}$, 6-CH), $2.87(1 \mathrm{H}, \mathrm{dm}, J=8.7 \mathrm{~Hz}, 5-\mathrm{CH}), 2.60-2.33\left(5 \mathrm{H}, \mathrm{m}, 1-\mathrm{CCH}_{2}, 8-\mathrm{CH}\right.$ and, 3- $\left.\mathrm{CH}_{2}\right)$, 2.15-2.03 (2H, m, 4- $\left.\mathrm{CH}_{2}\right), 1.89-1.74\left(2 \mathrm{H}, \mathrm{m}, 7-\mathrm{CH}_{2}\right), 1.64\left(6 \mathrm{H}, \mathrm{s}, 1-\mathrm{C}-\right.$ cis- $\mathrm{CH}_{3}$ and 1-C-trans$\left.\mathrm{CH}_{3}\right), 0.99\left(3 \mathrm{H}, \mathrm{d}, J=6.8 \mathrm{~Hz}, 8-\mathrm{CHCH}_{3}\right) ;{ }^{13} \mathrm{C} \mathrm{NMR}\left(100 \mathrm{MHz}, \mathrm{CDCl}_{3}\right) \delta 210.6$ (9-CO), 209.5 (2-CO), $134.2\left(1-\mathrm{CCH}_{2} \mathrm{CH}=\mathrm{C}\right), 119.4$ (1- $\left.\mathrm{CCH}_{2} \mathrm{CH}=\right), 75.5$ (6-CH), 71.7 (1-C), 52.6 (5$\mathrm{CH}), 39.6\left(3-\mathrm{CH}_{2}\right), 38.3(8-\mathrm{CH}), 36.3\left(7-\mathrm{CH}_{2}\right), 27.1\left(1-\mathrm{CCH}_{2}\right), 26.1$ (1-C-cis-CH$), 19.7$ (4$\left.\mathrm{CH}_{2}\right), 18.0\left(1-\mathrm{C}\right.$-trans- $\left.\mathrm{CH}_{3}\right), 15.8\left(8-\mathrm{CHCH}_{3}\right)$; endo-12: ${ }^{1} \mathrm{H} \mathrm{NMR}\left(400 \mathrm{MHz}, \mathrm{CDCl}_{3}\right) \delta 4.98$ $\left(1 \mathrm{H}, \mathrm{m}, 1-\mathrm{CCH}_{2} \mathrm{CH}=\right), 4.10(1 \mathrm{H}, \mathrm{dt}, J=11.1,5.4 \mathrm{~Hz}, 6-\mathrm{CH}), 2.99(1 \mathrm{H}$, app. t, $J=6.0 \mathrm{~Hz}, 5-$ $\mathrm{CH}), 2.58-2.43\left(5 \mathrm{H}, \mathrm{m}, 1-\mathrm{CCH}_{2}, 8-\mathrm{CH}\right.$ and $\left.3-\mathrm{CH}_{2}\right), 2.15-2.03\left(2 \mathrm{H}, \mathrm{m}, 4-\mathrm{CH}_{2}\right), 1.83-1.71$ $\left(2 \mathrm{H}, \mathrm{m}, 7-\mathrm{CH}_{2}\right), 1.64\left(6 \mathrm{H}, \mathrm{s}, 1-\mathrm{C}-\mathrm{cis}-\mathrm{CH}_{3}\right.$ and 1-C-trans- $\left.\mathrm{CH}_{3}\right), 0.96(3 \mathrm{H}, \mathrm{d}, J=6.8 \mathrm{~Hz}$, $\left.\mathrm{CHCH}_{3}\right) ;{ }^{13} \mathrm{C} \mathrm{NMR}\left(100 \mathrm{MHz}, \mathrm{CDCl}_{3}\right) 212.6$ (9-CO), 211.6 (2-CO), $135.0\left(1-\mathrm{CCH}_{2} \mathrm{CH}=\mathrm{C}\right)$, $118.5\left(1-\mathrm{CCH}_{2} \mathrm{CH}=\right), 71.3(6-\mathrm{CH}), 70.2(1-\mathrm{C}), 52.4(5-\mathrm{CH}), 40.2\left(3-\mathrm{CH}_{2}\right), 37.5(8-\mathrm{CH}), 37.4$ (7- $\left.\mathrm{CH}_{2}\right), 29.8\left(1-\mathrm{CCH}_{2}\right), 26.0$ (1-C-cis- $\left.\mathrm{CH}_{3}\right), 18.0\left(4-\mathrm{CH}_{2}\right), 17.8$ (1-C-trans-CH$\left.)_{3}\right), 15.7$ (8$\mathrm{CHCH}_{3}$ ). Traces of a third diastereoisomer were detected by ${ }^{13} \mathrm{C}$ NMR spectroscopy. HRMS (ESI-TOF) $[\mathrm{M}+\mathrm{H}]^{+} \mathrm{C}_{15} \mathrm{H}_{23} \mathrm{O}_{3}$ calcd. 251.1642, found 251.1640.

2-Hydroxy-5-methylbicyclo[3.2.1]octane-6,8-dione (13). To a solution of 2-methyl-1,3cyclopentanedione (100 mg, $0.89 \mathrm{mmol})$ in dry DMF (4 mL) was added acrolein $(72 \mathrm{mg}, 90$ $\mu \mathrm{L}, 1.3 \mathrm{mmol}$ ) at $25^{\circ} \mathrm{C}$. The solution was heated at reflux at $130{ }^{\circ} \mathrm{C}$ for $16 \mathrm{~h}$. After allowing to cool, water $(15 \mathrm{~mL})$ was added and the mixture was extracted with dichloromethane $(4 \mathrm{x}$ $15 \mathrm{~mL})$. The combined organic layers were washed with water $(3 \times 15 \mathrm{~mL})$, dried over $\mathrm{MgSO}_{4}$, filtered and evaporated to give ketol $13(90 \mathrm{mg}, 60 \%)$ as an 80:20 mixture of exo-13: endo-13: IR (film): 3450, 2933, 1765, 1723, $1453 \mathrm{~cm}^{-1}$; exo-13: ${ }^{1} \mathrm{H}$ NMR (400 MHz, $\mathrm{CDCl}_{3}$ ) d $4.57(1 \mathrm{H}, \mathrm{m}, 2-\mathrm{CH}), 3.03$ (1H, app. t, $J=5.4 \mathrm{~Hz}, 1-\mathrm{CH}), 2.70-2.52\left(2 \mathrm{H}, \mathrm{m}, 7-\mathrm{CH}_{2}\right), 2.25$ $(1 \mathrm{H}, \mathrm{m}, 4-\mathrm{CHeq}), 1.95-1.87\left(2 \mathrm{H}, \mathrm{m}, 3-\mathrm{CH}_{2}\right), 1.81-1.77(1 \mathrm{H}, \mathrm{m}, 4-\mathrm{CHax}), 1.07(3 \mathrm{H}, \mathrm{s}, 5-$ 
$\left.\mathrm{CCH}_{3}\right) ;{ }^{13} \mathrm{C}$ NMR (100 MHz, $\mathrm{CDCl}_{3}$ ) $\delta 214.5$ (8-CO), 211.1 (6-CO), 77.5 (2-CH), 59.3 (5$\left.\mathrm{CCH}_{3}\right), 52.7(1-\mathrm{CH}), 42.1\left(7-\mathrm{CH}_{2}\right), 40.1\left(4-\mathrm{CH}_{2}\right), 26.6\left(3-\mathrm{CH}_{2}\right), 12.2\left(5-\mathrm{CCH}_{3}\right)$; endo-13: ${ }^{1} \mathrm{H}$ NMR (400 MHz, $\left.\mathrm{CDCl}_{3}\right) \delta 4.25(1 \mathrm{H}, \mathrm{m}, 2-\mathrm{CH}), 3.08(1 \mathrm{H}, \mathrm{dd}, J=7.5,3.3 \mathrm{~Hz}, 1-\mathrm{CH}), 2.50-$ $2.43\left(2 \mathrm{H}, \mathrm{m}, 7-\mathrm{CH}_{2}\right), 2.25(1 \mathrm{H}, \mathrm{m}, 4-\mathrm{CHeq}), 1.95-1.75\left(3 \mathrm{H}, \mathrm{m}, 3-\mathrm{CH}_{2}\right.$ and 4-CHax), $1.06(3 \mathrm{H}$, s, 5- $\left.\mathrm{CCH}_{3}\right) ;{ }^{13} \mathrm{C} \mathrm{NMR}\left(100 \mathrm{MHz}, \mathrm{CDCl}_{3}\right) \delta 213.5$ (8-CO), $211.6(6-\mathrm{CO}), 73.6(2-\mathrm{CH}), 58.3$ (5- $\left.\mathrm{CCH}_{3}\right), 54.4(1-\mathrm{CH}), 38.7\left(7-\mathrm{CH}_{2}\right), 35.9\left(4-\mathrm{CH}_{2}\right), 27.1\left(3-\mathrm{CH}_{2}\right), 11.6\left(5-\mathrm{CCH}_{3}\right)$. HRMS (ESI-TOF) $[\mathrm{M}+\mathrm{H}]^{+} \mathrm{C}_{9} \mathrm{H}_{13} \mathrm{O}_{3}$ calcd. 169.0859, found 169.0861 .

2-Hydroxy-3,5-dimethylbicyclo[3.2.1]octane-6,8-dione (14). To a solution of 2-methyl-1,3cyclopentanedione $(100 \mathrm{mg}, 0.89 \mathrm{mmol})$ in dry acetonitrile $(6 \mathrm{~mL})$ were added methacrolein $(1.3 \mathrm{mmol}, 93 \mathrm{mg}, 73 \mu \mathrm{L})$ and DABCO $(0.18 \mathrm{mmol}, 20 \mathrm{mg})$ at $25{ }^{\circ} \mathrm{C}$. The solution was heated at reflux at $130{ }^{\circ} \mathrm{C}$ for $16 \mathrm{~h}$. After allowing to cool, water $(15 \mathrm{~mL})$ was added and the mixture extracted with dichloromethane $(4 \times 15 \mathrm{~mL})$. The combined organic layers were washed with water $(3 \times 15 \mathrm{~mL})$, dried over $\mathrm{MgSO}_{4}$, filtered and evaporated to give ketol 14 (80 mg, 50\%) as a 70:30 mixture of endo-14: exo-14; IR (film): 3499, 2933, 1767, 1724, $1455 \mathrm{~cm}^{-1}$; endo-14: ${ }^{1} \mathrm{H}$ NMR (400 MHz, $\mathrm{CDCl}_{3}$ ) $\delta 3.69(1 \mathrm{H}, \mathrm{dd}, J=9.6,3.2 \mathrm{~Hz}, 2-\mathrm{CH}), 3.03$ $(1 \mathrm{H}, \mathrm{dd}, J=7.5,3.3 \mathrm{~Hz}, 1-\mathrm{CH}), 2.96(1 \mathrm{H}, \mathrm{d}, J=19.4 \mathrm{~Hz}, 7-\mathrm{CHax}), 2.48$ (1H, dd, $J=19.4$, $7.5 \mathrm{~Hz}, 7-\mathrm{CHeq}), 1.92-1.67\left(3 \mathrm{H}, \mathrm{m}, 3-\mathrm{CH}\right.$ and $\left.4-\mathrm{CH}_{2}\right), 1.02\left(3 \mathrm{H}, \mathrm{s}, 5-\mathrm{CCH}_{3}\right), 1.01(3 \mathrm{H}, \mathrm{d}, J=$ $\left.6.6 \mathrm{~Hz}, 3-\mathrm{CHCH}_{3}\right) ;{ }^{13} \mathrm{C} \mathrm{NMR}\left(100 \mathrm{MHz}, \mathrm{CDCl}_{3}\right.$ ) $\delta 213.4$ (8-CO), 211.6 (6-CO), $78.9(2-\mathrm{CH})$, $59.4\left(5-\mathrm{CCH}_{3}\right), 53.7(1-\mathrm{CH}), 44.5\left(7-\mathrm{CH}_{2}\right), 39.1\left(4-\mathrm{CH}_{2}\right), 32.9\left(3-\mathrm{CHCH}_{3}\right), 17.3\left(3-\mathrm{CHCH}_{3}\right)$, $11.6\left(5-\mathrm{CCH}_{3}\right)\left(400 \mathrm{MHz}, \mathrm{CDCl}_{3}\right)$; exo-14: ${ }^{1} \mathrm{H} \mathrm{NMR}\left(400 \mathrm{MHz}, \mathrm{CDCl}_{3}\right) \delta 4.25(1 \mathrm{H}$, ddd, $J=$ 5.1, 3.4, $2.3 \mathrm{~Hz}, 2-\mathrm{CH}), 3.01(1 \mathrm{H}, \mathrm{m}, 1-\mathrm{CH}), 2.60-2.58\left(2 \mathrm{H}, \mathrm{m}, 7-\mathrm{CH}_{2}\right), 2.08(1 \mathrm{H}, \mathrm{m}, 3-$ CHeq), 1.92-1.67 (2H, m, 3-CH and 4-CHax), $1.03\left(3 \mathrm{H}, \mathrm{s}, 5-\mathrm{CCH}_{3}\right), 0.97(3 \mathrm{H}, \mathrm{d}, J=6.7 \mathrm{~Hz}$, 3- $\left.\mathrm{CHCH}_{3}\right) ;{ }^{13} \mathrm{C} \mathrm{NMR}\left(100 \mathrm{MHz}, \mathrm{CDCl}_{3}\right.$ ) $\delta 215.1$ (8-CO), 211.4 (6-CO), 79.6 (2-CH), 58.8 $\left(5-\mathrm{CCH}_{3}\right), 52.5(1-\mathrm{CH}), 46.7\left(7-\mathrm{CH}_{2}\right), 41.8\left(4-\mathrm{CH}_{2}\right), 30.2\left(3-\mathrm{CHCH}_{3}\right), 15.4\left(3-\mathrm{CHCH}_{3}\right), 12.0$ (5-CCH $\mathrm{C}_{3}$ ). HRMS (ESI-TOF) $[\mathrm{M}+\mathrm{H}]^{+} \mathrm{C}_{10} \mathrm{H}_{15} \mathrm{O}_{3}$ calcd. 183.1016, found 183.1014 .

2-Hydroxy-4,5-dimethylbicyclo[3.2.1]octane-6,8-dione (15). To a solution of 2-methyl-1,3cyclopentanedione (100 mg, $0.89 \mathrm{mmol})$ in dry acetonitrile $(6 \mathrm{~mL})$ were added crotonaldehyde $(1.3 \mathrm{mmol}, 93 \mathrm{mg}, 73 \mu \mathrm{L})$ and DABCO $(101 \mathrm{mg}, 0.90 \mathrm{mmol})$ at $25^{\circ} \mathrm{C}$. The resulting solution was heated at $95{ }^{\circ} \mathrm{C}$ for $16 \mathrm{~h}$. After allowing to cool, water $(15 \mathrm{~mL})$ was added and the mixture extracted with dichloromethane $(4 \times 15 \mathrm{~mL})$. The combined organic layers were washed with water $(3 \times 15 \mathrm{~mL})$, dried over $\mathrm{MgSO}_{4}$, filtered and evaporated to give ketol 15 (109 mg, 61\%) as a 37:50 mixture of mixture of endo-15: exo-15; IR (film): 3441, 2936, 1763, 1719, 1455, $1041 \mathrm{~cm}^{-1}$; endo-15: ${ }^{1} \mathrm{H}$ NMR (400 MHz, $\left.\mathrm{CDCl}_{3}\right) \delta 4.20(1 \mathrm{H}$, ddd, $J=11.1,5.9,3.4 \mathrm{~Hz}, 2-\mathrm{CH}), 3.04(1 \mathrm{H}, \mathrm{dd}, J=7.0,3.4 \mathrm{~Hz}, 1-\mathrm{CH}), 2.88(1 \mathrm{H}, \mathrm{d}, J=19.5$ Hz, 7-CHax), $2.56(1 \mathrm{H}, \mathrm{dd}, J=19.5,7.0 \mathrm{~Hz}, 7-\mathrm{CHeq}), 2.05(1 \mathrm{H}, \mathrm{dt}, J=14.4,5.5 \mathrm{~Hz}, 3-$ CHeq), $1.65(1 \mathrm{H}, \mathrm{m}, 4-\mathrm{CH}), 1.27(1 \mathrm{H}, \mathrm{m}, 3-\mathrm{CHax}), 0.98\left(3 \mathrm{H}, \mathrm{d}, J=5.0 \mathrm{~Hz}, 4-\mathrm{CHCH}_{3}\right), 0.88$ 
(3H, s, 5- $\left.\mathrm{CCH}_{3}\right) ;{ }^{13} \mathrm{C} \mathrm{NMR}\left(100 \mathrm{MHz}, \mathrm{CDCl}_{3}\right.$ ) $\delta 210.4$ (8-CO), 209.9 (6-CO), 71.8 (2-CH), $61.3\left(5-\mathrm{CCH}_{3}\right), 53.8(1-\mathrm{CH}), 39.7(4-\mathrm{CH}), 38.6\left(7-\mathrm{CH}_{2}\right), 36.3\left(3-\mathrm{CH}_{2}\right), 15.0\left(4-\mathrm{CHCH}_{3}\right), 9.79$ (5- $\left.\mathrm{CCH}_{3}\right)$; exo-15: ${ }^{1} \mathrm{H}$ NMR (400 MHz, $\left.\mathrm{CDCl}_{3}\right) \delta 4.48(1 \mathrm{H}, \mathrm{ddd}, J=5.1,4.1,1.6 \mathrm{~Hz}, 2-\mathrm{CH})$, $2.98(1 \mathrm{H}, \mathrm{m}, 1-\mathrm{CH}), 2.55-2.45\left(2 \mathrm{H}, \mathrm{m}, 7-\mathrm{CH}_{2}\right), 2.36(1 \mathrm{H}, \mathrm{m}, 4-\mathrm{CH}), 1.82(1 \mathrm{H}, \mathrm{ddt}, J=15.8$, 5.6, $1.3 \mathrm{~Hz}, 3-\mathrm{CHeq}), 1.55(1 \mathrm{H}, \mathrm{ddd}, J=15.8,13.1,3.9 \mathrm{~Hz}, 3-\mathrm{CHax}), 0.99$ (3H, d, $J=5.0 \mathrm{~Hz}$,


$\mathrm{CO}), 75.8(2-\mathrm{CH}), 62.4\left(5-\mathrm{CCH}_{3}\right), 52.1(1-\mathrm{CH}), 44.0(4-\mathrm{CH}) 42.0\left(7-\mathrm{CH}_{2}\right), 35.6\left(3-\mathrm{CH}_{2}\right), 15.1$ $\left(4-\mathrm{CHCH}_{3}\right), 10.0 \quad\left(5-\mathrm{CCH}_{3}\right)$. The ${ }^{1} \mathrm{H}$ NMR spectrum showed the presence of third diastereoisomer (13\%). HRMS (ESI-TOF) $[\mathrm{M}+\mathrm{H}]^{+} \mathrm{C}_{10} \mathrm{H}_{15} \mathrm{O}_{3}$ calcd. 183.1016, found 183.1012.

2-Hydroxy-5-methyl-4-phenylbicyclo[3.2.1]octane-6,8-dione (16). To a solution of 2methyl-1,3-cyclopentanedione $(100 \mathrm{mg}, 0.89 \mathrm{mmol})$ in dry acetonitrile $(6 \mathrm{~mL})$ were added cinnamaldehyde (176 mg, $168 \mu \mathrm{L}, 1.3 \mathrm{mmol})$ and DABCO $(99 \mathrm{mg}, 0.89 \mathrm{mmol})$ at $25^{\circ} \mathrm{C}$. The solution was heated at $95{ }^{\circ} \mathrm{C}$ for $16 \mathrm{~h}$. After allowing to cool, water $(15 \mathrm{~mL})$ was added and the mixture extracted with dichloromethane $(4 \times 15 \mathrm{~mL})$. The combined organic layers were washed with water $\left(3 \times 15 \mathrm{~mL}\right.$ ), dried over $\mathrm{MgSO}_{4}$, filtered and evaporated. Column chromatography (silica gel, 20:80 ethyl acetate:dichloromethane) gave ketol 16 (20 mg, 10\%) as a 60:40 mixture of mixture of endo-16: exo-16; IR (film): 3488, 2988, 1763, 1721, 1455 , $1046 \mathrm{~cm}^{-1}$; endo-16: ${ }^{1} \mathrm{H}$ NMR (400 MHz, $\left.\mathrm{CDCl}_{3}\right) \delta$ 7.34-7.26 (3H, m, $m$ - and $\left.p-\mathrm{H}\right), 7.03(2 \mathrm{H}$, $J=7.8,2.4 \mathrm{~Hz}, o-\mathrm{H}), 4.38(1 \mathrm{H}, \mathrm{ddd}, J=10.4,5.9,3.5 \mathrm{~Hz}, 2-\mathrm{CH}), 3.19(1 \mathrm{H}, \mathrm{dd}, J=7.5,3.5$ $\mathrm{Hz}, 1-\mathrm{CH}), 3.16(1 \mathrm{H}, J=19.0 \mathrm{~Hz}, 7-\mathrm{CHax}), 2.65(1 \mathrm{H}, J=14.0,4.8 \mathrm{~Hz}, 4-\mathrm{CH}), 2.60(1 \mathrm{H}, J=$ 19.0, 7.5 Hz, 7-CHeq), 2.29-2.23 (1H, m, 3-CHeq), 2.05 (1H, m, 3-CHax), 0.77 (3H, s, 5$\left.\mathrm{CCH}_{3}\right) ;{ }^{13} \mathrm{C}$ NMR (100 MHz, $\mathrm{CDCl}_{3}$ ) $\delta 212.5$ (6-CO), 210.3 (8-CO), 137.6 (ipso-phenyl), 128.7 (phenyl), 128.6 (phenyl), 128.1 (phenyl), 71.7 (2- $\mathrm{CH}), 61.7\left(5-\mathrm{CCH}_{3}\right), 54.3(1-\mathrm{CH})$, $50.6(4-\mathrm{CH}), 38.8\left(7-\mathrm{CH}_{2}\right), 35.3\left(3-\mathrm{CH}_{2}\right), 10.7\left(5-\mathrm{CCH}_{3}\right)$; exo-16: ${ }^{1} \mathrm{H}$ NMR (400 MHz, $\left.\mathrm{CDCl}_{3}\right) \delta 7.34-7.26(3 \mathrm{H}, \mathrm{m}, m-$ and $p-\mathrm{H}), 7.07(2 \mathrm{H}, J=7.8,2.4 \mathrm{~Hz}, o-\mathrm{H}), 4.63(1 \mathrm{H}, \mathrm{ddd}, J=$ 5.2, 3.5, $1.7 \mathrm{~Hz}, 2-\mathrm{CH}), 3.41(1 \mathrm{H}, \mathrm{dd}, J=13.7,4.8 \mathrm{~Hz}, 4-\mathrm{CH}), 3.13(1 \mathrm{H}, \mathrm{dd}, J=8.0,4.5 \mathrm{~Hz}$, 1-CH), 2.68-2.56 (2H, m, 7-CH $\mathrm{CH}_{2}, 2.26(1 \mathrm{H}, \mathrm{m}, 3-\mathrm{CHeq}), 2.04(1 \mathrm{H}, \mathrm{m}, 3-\mathrm{CHax}), 0.79(3 \mathrm{H}, \mathrm{s}$, 5-CCH$)_{3}$ ); ${ }^{13} \mathrm{C}$ NMR (100 MHz, $\mathrm{CDCl}_{3}$ ) $\delta 213.1$ (8-CO), 212.5 (6-CO), 138.0 (ipso-phenyl), 128.7 (phenyl), 128.6 (phenyl), 128.1 (phenyl), 75.1 (2-CH), $62.7\left(5-\mathrm{CCH}_{3}\right), 54.1(1-\mathrm{CH})$, $52.6(4-\mathrm{CH}), 42.0 \quad\left(7-\mathrm{CH}_{2}\right), 34.8 \quad\left(3-\mathrm{CH}_{2}\right), 11.0 \quad\left(5-\mathrm{CCH}_{3}\right)$; HRMS (ESI-TOF) $[\mathrm{M}+\mathrm{H}]^{+}$ $\mathrm{C}_{15} \mathrm{H}_{17} \mathrm{O}_{3}$ calcd. 245.1172, found 245.1172 .

6-Hydroxy-1-methyl-8-phenylbicyclo[3.3.1]nonane-2,9-dione (17). To a solution of 2methyl-1,3-cyclohexanedione (100 mg, $0.79 \mathrm{mmol})$ in $\mathrm{CH}_{3} \mathrm{CN}(6 \mathrm{~mL})$ at $25{ }^{\circ} \mathrm{C}$ were added cinnamaldehyde (155 mg, $1.1 \mathrm{mmol}, 150 \mu \mathrm{L})$ and DABCO (89 mg, $0.79 \mathrm{mmol})$. The solution was heated at $95{ }^{\circ} \mathrm{C}$ for $16 \mathrm{~h}$. After allowing to cool, water $(15 \mathrm{~mL})$ was added and the 
mixture extracted with dichloromethane $(4 \times 10 \mathrm{~mL})$. The combined organic layers were washed with water $(3 \times 15 \mathrm{~mL})$, dried over $\mathrm{MgSO}_{4}$, filtered and evaporated. Column chromatography (silica gel, 1:9 ethyl acetate:dichloromethane) gave 17 (22 $\mathrm{mg}, 10 \%)$ as a yellow oil, a 70:30 mixture of endo-17: exo-17; IR (film): 3443, 2927, 1725, 1691, 1496, 1041. endo-17: ${ }^{1} \mathrm{H}$ NMR (400 MHz, $\mathrm{CDCl}_{3}$ ) $\delta$ 7.32-7.26 (3H, m, 3,4,5-phenyl), 7.03-6.97 (2H, m, 2,6-phenyl), 4.34 (1H, dt, $J=11.0,5.5 \mathrm{~Hz}, 6-\mathrm{CH}), 3.09$ (1H, app. t, $J=5.5 \mathrm{~Hz}, 5-$ $\mathrm{CH}), 2.75$ (1H, m, 3-CHeq), 2.81-2.70 (2H, m, 3-CHax and 8-CH), 2.58 (1H, m, 4-CHeq), 2.44-2.25 (2H, m, 7-CH $), 1.82(1 \mathrm{H}, \mathrm{m}, 4-\mathrm{CHax}), 0.95\left(3 \mathrm{H}, \mathrm{s}, 1-\mathrm{CCH}_{3}\right) ;{ }^{13} \mathrm{C}$ NMR $(100 \mathrm{MHz}$, $\left.\mathrm{CDCl}_{3}\right) \delta 208.5$ (9-CH), 208.0 (2-CH), 138.2 (ipso-phenyl), 128.7 (phenyl), 128.6 (phenyl), 128.5 (phenyl), $71.2(6-\mathrm{CH}), 68.9(1-\mathrm{C}), 52.8(5-\mathrm{CH}), 51.2(8-\mathrm{CH}), 40.2\left(3-\mathrm{CH}_{2}\right), 37.0$ (7$\left.\mathrm{CH}_{2}\right), 17.2\left(4-\mathrm{CH}_{2}\right), 15.0\left(1-\mathrm{CCH}_{3}\right) ;$ exo-17: ${ }^{1} \mathrm{H} \mathrm{NMR}\left(400 \mathrm{MHz}, \mathrm{CDCl}_{3}\right) \delta$ 7.32-7.26 (3H, m, 3,4,5-phenyl), 7.03-6.97 (2H, m, 2,6-phenyl), $4.52(1 \mathrm{H}, \mathrm{dd}, J=2.5,2.2 \mathrm{~Hz}, 6-\mathrm{CH}), 3.45(1 \mathrm{H}$, $\mathrm{dd}, J=13.9,4.7 \mathrm{~Hz}, 5-\mathrm{CH}), 2.96(1 \mathrm{H}, \mathrm{m}, 3-\mathrm{CHeq}), 2.81-2.70(2 \mathrm{H}, \mathrm{m}, 3-\mathrm{CHax}$ and $8-\mathrm{CH})$, 2.65-2.62 (1 H, m, 4-CHeq), 2.44-2.45 (2H, m, 7- $\left.\mathrm{CH}_{2}\right), 2.11$ (1H, m, 4-CHax), 1.00 (3H, s, 1$\left.\mathrm{CCH}_{3}\right) ;{ }^{13} \mathrm{C}$ NMR $\left(100 \mathrm{MHz}, \mathrm{CDCl}_{3}\right) \delta 209.2$ (9-CH), 207.8 (2-CH), 138.5 (ipso-phenyl), 128.7 (phenyl), 128.6 (phenyl), 128.5 (phenyl), 75.0 (6-CH), 70.4 (1-C), $53.0(5-\mathrm{CH}), 52.2$ (8-CH), $39.0\left(3-\mathrm{CH}_{2}\right), 36.0\left(7-\mathrm{CH}_{2}\right), 20.7\left(4-\mathrm{CH}_{2}\right), 15.1\left(1-\mathrm{CCH}_{3}\right)$. HRMS (ESI-TOF): $\mathrm{m} / \mathrm{z}$ $[\mathrm{M}+\mathrm{H}]^{+} \mathrm{C}_{16} \mathrm{H}_{18} \mathrm{O}_{3}$ calcd 259.1329, found 259.1328.

6-Hydroxy-1,3,3,7-tetramethylbicyclo[3.3.1]nonane-2,9-dione (18). To a solution of 2,4,4trimethylcyclohexane-1,3-dione $(0.20 \mathrm{~g}, 1.28 \mathrm{mmol})$ in dry acetonitrile $(10 \mathrm{~mL})$ were added methacrolein (134 mg, $0.16 \mathrm{~mL}, 1.92 \mathrm{mmol})$ and DABCO $(143 \mathrm{mg}, 1.28 \mathrm{mmol})$ at $25^{\circ} \mathrm{C}$. The solution was heated at $95{ }^{\circ} \mathrm{C}$ for $16 \mathrm{~h}$. After this time the reaction was allowed to cool to 25 ${ }^{\circ} \mathrm{C}$ then evaporated. Water $(15 \mathrm{~mL})$ was then added and the mixture extracted with dichloromethane $(2 \times 15 \mathrm{~mL})$. The combined organic layers were washed with water $(2 \times 15$ $\mathrm{mL}$ ) then with and brine, dried over $\mathrm{MgSO}_{4}$, filtered and evaporated to give ketol 18 (186 mg, $65 \%$ ) as a colourless oil (mixture of diastereoisomers approx. 43:41:14:2 and confirmed by oxidation to 20): ${ }^{1} \mathrm{H}$ NMR (400 MHz, $\left.\mathrm{CDCl}_{3}\right) \delta 3.93$ and $3.78(1 \mathrm{H}, \mathrm{m}), 3.50(1 \mathrm{H}, \mathrm{dd}, J=10.5$, $4.5 \mathrm{~Hz}$ ), 3.15-2.63 (2H, m), 2.40-0.90 (16H, m); ${ }^{13} \mathrm{C} \mathrm{NMR} \mathrm{(100} \mathrm{MHz,} \mathrm{CDCl}_{3}$ ) $\delta 216.4,216.1$, 215.2, 213.8, 213.40, 212.1, 211.7, 207.5, 83.9, 83.1, 81.2, 79.3, 77.4, 59.9, 59.8, 59.3, 53.0, 51.9, 51.7, 46.2, 45.8, 45.72, 45.4, 45.3, 44.1, 43.4, 37.1, 35.3, 33.4, 31.9, 31.5, 31.4, 29.4, 27.4, 26.3, 26.1, 26.1, 25.8, 25.5, 25.3, 24.6, 24.1, 19.2, 18.6, 18.5, 18.3, 17.2, 16.5; $\mathrm{m} / \mathrm{z}\left(\mathrm{EI}^{+}\right.$, \%) 225 (3), $224\left(\mathrm{M}^{+}, 17\right), 196$ (6), 138 (52), 123 (100); HRMS M+ $\mathrm{C}_{13} \mathrm{H}_{20} \mathrm{O}_{3}$ calcd. 224.1407, found 224.1408 .

6-Hydroxy-1,3,3,8-tetramethylbicyclo[3.3.1]nonane-2,9-dione (19). To a solution of 2,4,4trimethylcyclohexane-1,3-dione (100 mg, $0.64 \mathrm{mmol})$ in dry acetonitrile $(6 \mathrm{~mL})$ were added crotonaldehyde $(0.96 \mathrm{mmol}, 67 \mathrm{mg}, 80 \mu \mathrm{L})$ and DABCO $(0.64 \mathrm{mmol}, 72 \mathrm{mg})$ at $25{ }^{\circ} \mathrm{C}$. The resulting solution was heated at $95{ }^{\circ} \mathrm{C}$ for $16 \mathrm{~h}$. After allowing to cool, water $(15 \mathrm{~mL})$ was 
added and the mixture extracted with dichloromethane $(4 \times 15 \mathrm{~mL})$. The combined organic layers were washed with water $(3 \times 10 \mathrm{~mL})$, dried over $\mathrm{MgSO}_{4}$, filtered and evaporated to give 19 (71 $\mathrm{mg}, 49 \%$ ) as a pale yellow oil, (mixture of diastereoisomers approx. 41:28:26:5 and confirmed by oxidation to 21); IR (film): 3405, 2972, 2937, 1726, 1694, 1496, 1061, $1034 \mathrm{~cm}^{-1} ;{ }^{1} \mathrm{H}$ NMR (400 MHz, $\left.\mathrm{CDCl}_{3}\right) \delta 4.25$ and $4.00(1 \mathrm{H}, \mathrm{m}), 3.20$ and $2.90(1 \mathrm{H}, \mathrm{m}), 2.70$ $1.20(5 \mathrm{H}, \mathrm{m}), 1.25-0.80(12 \mathrm{H}, \mathrm{m}) ;{ }^{13} \mathrm{C} \mathrm{NMR}\left(100 \mathrm{MHz}, \mathrm{CDCl}_{3}\right) \delta 216.9,216.8,214.9,214.0$, 213.6, 212.5, 211.5, 80.9, 76.3, 72.6, 70.6, 63.8, 63.6, 62.5, 61.9, 52.4, 52.2, 51.7, 51.2, 46.0, 45.7, 45.6, 45.4, 45.3, 42.6, 41.1, 39.8, 36.2, 36.1, 36.0, 34.6, 34.2, 31.9, 30.9, 30.7, 27.3, 27.1, 26.6, 26.5, 24.7, 24.6, 24.3, 24.1, 17.1, 17.0 (2 lines), 16.9, 16.4, 15.7, 15.6, 14.6; m/z ( $\left.\mathrm{EI}^{+}, \%\right) 225$ (8), $224\left(\mathrm{M}^{+}, 58\right), 196$ (14), 178 (22), 138 (88), 123 (100); HRMS M+ $\mathrm{C}_{13} \mathrm{H}_{20} \mathrm{O}_{3}$ calcd. 224.1407, found 224.1408.

1,3,3,7-exo-Tetramethylbicyclo[3.3.1]nonane-2,6,9-trione (20). To a solution of 6hydroxy-1,3,3,7-tetramethylbicyclo[3.3.1]nonane-2,9-dione (18, $200 \mathrm{mg}, 0.90 \mathrm{mmol})$ in dry dichloromethane $(10 \mathrm{~mL})$ was added pyridinium chlorochromate $(230 \mathrm{mg}, 1.08 \mathrm{mmol})$ and the resulting dark solution was stirred at $25^{\circ} \mathrm{C}$ for $16 \mathrm{~h}$. After allowing to cool, the solution was filtered through a pad of $\mathrm{Celite}^{\circledR}$ and the filtrate was evaporated. The residue was dissolved in ethyl acetate, the mixture filtered through a pad of silica, and the filtrate evaporated to give an 85:15 mixture of epimers. On standing for 2 weeks, the mixture afforded trione 20 (191 mg, 94\%) as pale green needles, m.p. 94-95 ${ }^{\circ} \mathrm{C}$; IR (film): 2262, 1716, 1699, 1270, $1037 \mathrm{~cm}^{-1}$; ${ }^{1} \mathrm{H}$ NMR $\left(400 \mathrm{MHz}, \mathrm{CD}_{3} \mathrm{CN}\right) \delta 3.69(1 \mathrm{H}, \mathrm{dd}, J=10.8,1.7 \mathrm{~Hz}$, 5-CH), 2.51 (1H, app. septet, $J=10.8 \mathrm{~Hz}, 7-\mathrm{CH}), 2.31$ (1H, dd, $J=14.5,10.8 \mathrm{~Hz}, 4-\mathrm{CHeq})$, 2.32-2.22 (2H, m, 8- $\left.\mathrm{CH}_{2}\right), 1.75(1 \mathrm{H}, \mathrm{d}(\mathrm{br}), J=14.5 \mathrm{~Hz}, 4-\mathrm{CHax}), 1.25\left(3 \mathrm{H}, \mathrm{s}, 3-\mathrm{CCH}_{3}\right.$ eq), $1.13\left(3 \mathrm{H}, \mathrm{s}, 1-\mathrm{CCH}_{3}\right), 1.00\left(3 \mathrm{H}, \mathrm{s}, 3-\mathrm{CCH}_{3} \mathrm{ax}\right), 0.98\left(3 \mathrm{H}, \mathrm{d}, J=6.3 \mathrm{~Hz} 7-\mathrm{CHCH}_{3}\right) ;{ }^{13} \mathrm{C} \mathrm{NMR}$ (100 MHz, $\left.\mathrm{CD}_{3} \mathrm{CN}\right) \delta 215.6$ (2-CO), 206.7 (9-CO), 205.4 (6-CO), 64.8 (5-CH), 60.6 (1-C), $45.6(3-\mathrm{C}), 41.7\left(8-\mathrm{CH}_{2}\right), 38.9\left(7-\mathrm{CHCH}_{3}\right), 36.4\left(4-\mathrm{CH}_{2}\right), 26.3\left(2-\mathrm{CCH}_{3} e q\right), 24.3\left(2-\mathrm{CCH}_{3} a x\right)$, $18.7\left(1-\mathrm{CCH}_{3}\right), 13.7$ (7- $\left.\mathrm{CHCH}_{3}\right) ; \mathrm{m} / z\left(\mathrm{EI}^{+}, \%\right) 223$ (9), $222\left(\mathrm{M}^{+}, 66\right), 194$ (36), 138 (100), 123 (97); HRMS $\mathrm{M}^{+} \mathrm{C}_{13} \mathrm{H}_{18} \mathrm{O}_{3}$ calcd. 222.1251, found 222.1251.

1,3,3,8-Tetramethylbicyclo[3.3.1]nonane-2,6,9-trione (21). To a solution of 6-hydroxy1,3,3,8-tetramethylbicyclo[3.3.1]nonane-2,9-dione $(\mathbf{1 9}, \quad 50 \quad \mathrm{mg}, \quad 0.2 \mathrm{mmol})$ in dry dichloromethane $(3 \mathrm{~mL})$ was added pyridinium chlorochromate $(0.26 \mathrm{mmol}, 57 \mathrm{mg})$ and the mixture was stirred at $25{ }^{\circ} \mathrm{C}$ for $16 \mathrm{~h}$. The mixture was then filtered through a pad of Celite ${ }^{\circledR}$ and the filtrate was evaporated. The residue was dissolved in ethyl acetate, filtered through a pad of silica and the filtrate evaporated. The residue was purified by flash column chromatography (silica gel, 1:9 ethyl acetate:dichloromethane) to give trione 21 (15 mg, 30\%) as a 70:30 mixture of 8-endo-21: 8-exo-21. IR (film): 2975, 1741, 1716, 1698, $1455 \mathrm{~cm}^{-1}$; 8endo-21: ${ }^{1} \mathrm{H}$ NMR $\left(400 \mathrm{MHz}, \mathrm{CDCl}_{3}\right) \delta 3.71(1 \mathrm{H}, \mathrm{dt}, J=10.7,1.5 \mathrm{~Hz}, 5-\mathrm{CH}), 2.57(1 \mathrm{H}, \mathrm{dd}, J$ 
$=15.5,6.3 \mathrm{~Hz}, 7-\mathrm{CHeq}), 2.47(1 \mathrm{H}, \mathrm{m}, 8-\mathrm{CH}), 2.35-2.21$ (2H, m, 7-CHax and 4-CHeq), 1.68 $(1 \mathrm{H}, \mathrm{m}, 4-\mathrm{CHax}), 1.31\left(3 \mathrm{H}, \mathrm{s}, 3-\mathrm{CCH}_{3} \mathrm{eq}\right), 1.18\left(3 \mathrm{H}, \mathrm{s}, 1-\mathrm{CCH}_{3}\right), 1.08\left(3 \mathrm{H}, \mathrm{s}, 3-\mathrm{CCH}_{3} \mathrm{ax}\right)$, $0.82\left(3 \mathrm{H}, \mathrm{d}, J=7.2 \mathrm{~Hz}, 8-\mathrm{CHCH}_{3}\right) ;{ }^{13} \mathrm{C} \mathrm{NMR}\left(100 \mathrm{MHz}, \mathrm{CDCl}_{3}\right) \delta 215.2$ (2-CO), 205.0 (9$\mathrm{CO}), 204.2$ (6-CO), $64.4(5-\mathrm{CH}), 63.0(1-\mathrm{C}), 45.2(3-\mathrm{C}), 42.6$ (7- $\left.\mathrm{CH}_{2}\right), 37.4(8-\mathrm{CH}), 36.9$ (4$\left.\mathrm{CH}_{2}\right), 27.0$ (3- $\left.\mathrm{CCH}_{3} \mathrm{eq}\right), 24.8$ (3- $\left.\mathrm{CCH}_{3} \mathrm{ax}\right), 16.6\left(1-\mathrm{CCH}_{3}\right), 15.3\left(8-\mathrm{CHCH}_{3}\right) ;$ 8-exo-21: ${ }^{1} \mathrm{H}$ NMR (400 MHz, $\left.\mathrm{CDCl}_{3}\right) \delta 3.73(1 \mathrm{H}, \mathrm{dt}, J=10.8,1.8 \mathrm{~Hz}, 5-\mathrm{CH}), 2.41(1 \mathrm{H}, \mathrm{dd}, J=4.7,1.8$ $\mathrm{Hz}, 7-\mathrm{CHeq}$ ), 2.32-2.05 (3H, m, 7-CHeq, 4-CHeq and 8-CH), 1.75 (1H, m, 4-CHax), 1.36 $\left(3 \mathrm{H}, \mathrm{s}, 3-\mathrm{CCH}_{3} \mathrm{eq}\right), 1.22\left(3 \mathrm{H}, \mathrm{d}, J=6.7 \mathrm{~Hz}, 8-\mathrm{CHCH}_{3}\right), 1.17\left(3 \mathrm{H}, \mathrm{s}, 1-\mathrm{CCH}_{3}\right), 1.02(3 \mathrm{H}, \mathrm{s}, 3-$ $\left.\mathrm{CCH}_{3} \mathrm{ax}\right) ;{ }^{13} \mathrm{C}$ NMR (100 MHz, $\mathrm{CDCl}_{3}$ ) $\delta 213.6$ (2-CO), 205.5 (9-CO), 203.8 (6-CO), 63.1 (5$\mathrm{CH}), 62.0$ (1-C), 45.1 (3-C), $43.8\left(7-\mathrm{CH}_{2}\right), 37.2\left(4-\mathrm{CH}_{2}\right), 35.8(8-\mathrm{CH}), 27.4\left(3-\mathrm{CCH}_{3} \mathrm{eq}\right), 24.7$ (3- $\left.\mathrm{CCH}_{3} \mathrm{ax}\right), 17.3\left(1-\mathrm{CCH}_{3}\right), 15.1\left(8-\mathrm{CHCH}_{3}\right) ; \mathrm{m} / z\left(\mathrm{EI}^{+}, \%\right) 223$ (7), $222\left(\mathrm{M}^{+}, 49\right), 194$ (19), 179 (62); HRMS $\mathrm{M}^{+} \mathrm{C}_{13} \mathrm{H}_{18} \mathrm{O}_{3}$ calcd. 222.1251, found 222.1251 .

1,3,3-Trimethylbicyclo[3.3.1]nonane-2,6,9-trione (22). To a solution of 6-hydroxy-1,3,3trimethylbicyclo[3.3.1]nonane-2,9-dione $(9)(75 \mathrm{mg}, 0.36 \mathrm{mmol})$ in dry dichloromethane (3 $\mathrm{mL})$ was added pyridinium chlorochromate $(92 \mathrm{mg}, 0.43 \mathrm{mmol})$ and the dark solution was stirred at $25{ }^{\circ} \mathrm{C}$ for $16 \mathrm{~h}$. The mixture was then filtered through a pad of Celite ${ }^{\circledR}$ and the filtrate was evaporated. The residue was dissolved in ethyl acetate, the solution filtered through a pad of silica and the filtrate was evaporated to give trione $22(50 \mathrm{mg}, 67 \%)$ as a white solid, m.p. 99-104 ${ }^{\circ} \mathrm{C} ;{ }^{1} \mathrm{H}$ NMR $\left(400 \mathrm{MHz}, \mathrm{CD}_{3} \mathrm{CN}\right) \delta 3.65(1 \mathrm{H}, \mathrm{d}, J=10.8 \mathrm{~Hz}, 5-\mathrm{CH})$, 2.45 (1H, m, 7-CHeq), 2.37-2.25 (2H, m, 4-CHeq and 7-CHax), 2.21 (1H, app. dd, $J=13.3$, 7.6 Hz, 8-CHeq), 1.72 (1H, m, 4-CHax), 1.47 (1H, td, $J=13.3,5.3 \mathrm{~Hz}, 8-\mathrm{CHax}), 1.26$ (3H, s, $\left.3-\mathrm{CCH}_{3} \mathrm{eq}\right), 1.13\left(3 \mathrm{H}, \mathrm{s}, 1-\mathrm{CCH}_{3}\right), 1.01\left(3 \mathrm{H}, \mathrm{s}, 3-\mathrm{CCH}_{3} \mathrm{ax}\right) ;{ }^{13} \mathrm{C} \mathrm{NMR}\left(100 \mathrm{MHz}, \mathrm{CD}_{3} \mathrm{CN}\right) \delta$ 215.5 (2-CO), 206.0 (9-CO), * 205.8 (6-CO), * $65.1(5-\mathrm{CH}), 59.8\left(1-\mathrm{CCH}_{3}\right), 45.7$ (3-C), 36.3 (7- $\left.\mathrm{CH}_{2}\right), 35.3\left(4-\mathrm{CH}_{2}\right), 33.1\left(8-\mathrm{CH}_{2}\right), 26.2\left(3-\mathrm{CCH}_{3}\right), 24.4\left(3-\mathrm{CCH}_{3}\right), 18.9\left(1-\mathrm{CCH}_{3}\right) ; m / z\left(\mathrm{EI}^{+}\right.$, \%) 209 (8), 208 (M+, 62), 180 (53), 138 (68), 123 (100), 110 (52); HRMS M $\mathrm{C}_{12} \mathrm{H}_{16} \mathrm{O}_{3}$ calcd. 208.1094, found 208.1094.

1-Methylbicyclo[3.3.1]nonane-2,6,9-trione (23). To a solution of 6-hydroxy-1methylbicyclo[3.3.1]nonane-2,9-dione $(6)(40 \mathrm{mg}, 0.22 \mathrm{mmol})$ in dry dichloromethane was added pyridinium chlorochromate $(56 \mathrm{mg}, 0.26 \mathrm{mmol})$ in one portion at $25^{\circ} \mathrm{C}$ and stirred for $16 \mathrm{~h}$. The mixture was then filtered through a pad of Celite ${ }^{\circledR}$ and evaporated. The residue was dissolved in ethyl acetate, the solution passed through a pad of silica and the filtrate evaporated to give trione $\mathbf{2 3}$ (30 mg, 76\%) as a pale green powder, m.p. $97-99{ }^{\circ} \mathrm{C}$. IR (film): 1711, 1453, 1246, 1036, $1029 \mathrm{~cm}^{-1}$; ${ }^{1} \mathrm{H}$ NMR $\left(400 \mathrm{MHz}, \mathrm{CD}_{3} \mathrm{CN}\right) \delta 3.45(1 \mathrm{H}, \mathrm{t}, J=5.0 \mathrm{~Hz}, 5-$ $\mathrm{CH}), 2.70-2.55\left(4 \mathrm{H}, \mathrm{m}, 7-\mathrm{CH}_{2}\right.$ and $\left.8-\mathrm{CH}_{2}\right), 2.53(1 \mathrm{H}, \mathrm{m}, 3-\mathrm{COCHeq}), 2.12-2.03(2 \mathrm{H}, \mathrm{m}, 4-$ $\mathrm{CH}_{2}$ ), 1.75 (1H, m, 3-CHax), $1.22\left(3 \mathrm{H}, \mathrm{s}, \mathrm{CH}_{3}\right) ;{ }^{13} \mathrm{C} \mathrm{NMR}\left(100 \mathrm{MHz}, \mathrm{CD}_{3} \mathrm{CN}\right) \delta 209.9$ (9CO), 208.0 (2-CO), 204.6 (6-CO), 64.5 (5-CH), 63.9 (1-C), $37.9\left(3-\mathrm{CH}_{2}\right), 37.5\left(7-\mathrm{CH}_{2}\right), 32.1$ 
(8- $\left.\mathrm{CH}_{2}\right), 23.4\left(4-\mathrm{CH}_{2}\right), 16.5\left(\mathrm{CH}_{3}\right)$; HRMS (ESI-TOF) $[\mathrm{M}+\mathrm{H}]^{+} \mathrm{C}_{10} \mathrm{H}_{13} \mathrm{O}_{3}$ calcd. 181.0859, found 181.0857 .

1,7-exo-Dimethylbicyclo[3.3.1]nonane-2,6,9-trione (24). To a solution of 6-hydroxy-1,7dimethylbicyclo[3.3.1]nonane-2,9-dione (10) $(50 \mathrm{mg}, 0.25 \mathrm{mmol})$ in dry dichloromethane was added pyridinium chlorochromate $(66 \mathrm{mg}, 0.30 \mathrm{mmol})$ in one portion at $25^{\circ} \mathrm{C}$, and the mixture was stirred for $16 \mathrm{~h}$. The mixture was then filtered through a pad of Celite ${ }^{\circledR}$ and the filtrate was evaporated. The residue was dissolved in ethyl acetate and the solution passed through a pad of silica. The filtrate was evaporated to give trione $\mathbf{2 4}(37 \mathrm{mg}, 77 \%)$ as a light green oil; IR (film): 2983, 2988, 1740, 1709, 1457, $1038 \mathrm{~cm}^{-1} ;{ }^{1} \mathrm{H}$ NMR (400 MHz, $\mathrm{CD}_{3} \mathrm{CN}$ ) $\delta 3.54(1 \mathrm{H}, \mathrm{dd}, J=7.2,2.6 \mathrm{~Hz}, 5-\mathrm{CH}), 2.75-2.52\left(3 \mathrm{H}, \mathrm{m}, 7-\mathrm{CH}\right.$ and $\left.3-\mathrm{CH}_{2}\right), 2.25-2.15(3 \mathrm{H}$, m, 8- $\mathrm{CH}_{2}$ and 4-CHH), $2.04(1 \mathrm{H}, \mathrm{m}, 4-\mathrm{CH} H), 1.20\left(3 \mathrm{H}, \mathrm{s}, 1-\mathrm{CCH}_{3}\right), 1.04(3 \mathrm{H}, \mathrm{d}, J=6.3 \mathrm{~Hz}$,

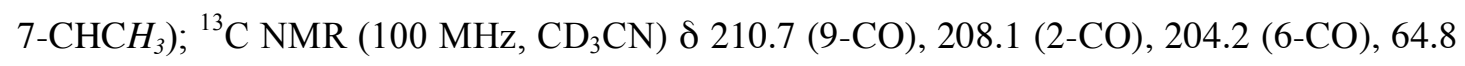
(5-CH), $64.6(1-\mathrm{C}), 41.6(7-\mathrm{CH}), 41.1\left(8-\mathrm{CH}_{2}\right), 37.6\left(3-\mathrm{CH}_{2}\right), 22.5\left(4-\mathrm{CH}_{2}\right), 16.5\left(1-\mathrm{CCH}_{3}\right)$, $14.5\left(7-\mathrm{CHCH}_{3}\right) ; m / z\left(\mathrm{EI}^{+}, \%\right) 194\left(\mathrm{M}^{+}, 34\right), 166$ (19), 152 (20), 140 (30), 69 (100); HRMS $\mathrm{M}^{+} \mathrm{C}_{11} \mathrm{H}_{14} \mathrm{O}_{3}$ calcd. 194.0937, found 194.0938.

Acknowledgment. The assistance of Dr. Anders Poulsen (Experimental Therapeutics Centre (ETC), A*STAR, Singapore in performing computational calculations and of Ms Doris Tan (ICES) for high-resolution mass spectrometric measurements is gratefully acknowledged. Financial support for a studentship (to R. P.) from the EPSRC Centre for Doctoral Training in Molecular Modelling \& Materials Science, University College London and from the A*STAR Graduate Academy (A*GA), Singapore is also gratefully acknowledged.

\section{References}

1. R. D. Taylor, M. MacCoss and A. D. G. Lawson, J. Med. Chem., 2014, 57, 5845.

2. C. M. Marson, Chem. Soc. Rev., 2011, 40, 5514.

3. (a) J. A. Peters, Synthesis, 1979, 321; (b) E. Butkus, Synlett., 2001, 1827.

4. (a) M.-H. Filippini and J. Rodriguez, Chem. Rev., 1999, 99, 27; (b) M. Presset, Y. Coquerel and J. Rodriguez, Chem. Rev., 2013, 113, 525.

5. F. Lovering, J. Bikker and C. Humblet, J. Med. Chem., 2009, 52, 6752.

6. J.-A. Richard, R. H. Pouwer and D. Y.-K. Chen, Angew. Chem. Int. Ed., 2012, 51, 4536.

7. J.-A. Richard, Eur. J. Org. Chem., 2014, 273.

8. J. T. Njardarson, Tetrahedron, 2011, 67, 7631.

9. (a) B. A. Sparling, D. C. Moebius and M. D. Shair, J. Am. Chem. Soc., 2013, 135, 644; (b) B. A. Sparling, J. K. Tucker, D. C. Moebius and M. D. Shair, Org. Lett., 2015, 17, 3398.

10. P. Adam, D. Arigoni, A. Bacher and W. Eisenreich, J. Med.Chem., 2002, 45, 4786.

11. J. H. Boyce and J. A. Porco, Jr., Angew. Chem. Int. Ed., 2014, 53, 7832.

12. J. Qi and J. A. Porco, Jr., J. Am. Chem. Soc., 2007, 129, 12682.

13. (a) J. Qi, A. B. Beeler, Q. Zhang, and J. A. Porco, Jr., J. Am. Chem. Soc., 2010, 132, 13642; (b) Q. Zhang, B. Mitasev and J. A. Porco, Jr., J. Am. Chem. Soc., 2010, 132, 14212.

14. A. J. Grenning, J. H. Boyce and J. A. Porco, Jr, J. Am. Chem. Soc., 2014, 136, 11799.

15. F. Buono and A. Tenaglia, Synlett., 1998, 1153. 
16. K.-H. Schönwälder, P. Kollatt, J. J. Stezowski and F. Effenberger, Chem. Ber., 1984, 117, 3280 .

17. S. J. Spessard and B. M. Stoltz, Org. Lett., $2002,4,1943$.

18. V. Rodeschini, N. M. Ahmad and N. S. Simpkins, Org. Lett., 2006, 8, 5283.

19. C. M. R. Volla, I. Atodiresei and M. Rueping, Chem. Rev., 2014, 114, 2390.

20. T. Pouplin, B. Tolon, P. Nuhant, B. Delpech and C. Marazano, Eur. J. Org. Chem., 2007, 5117.

21. K. C. Nicolaou, G. E. A. Carenzi and V. Jeso, Angew. Chem. Int. Ed., 2005, 44, 3895.

22. T. Boddaert, Y. Coquerel and J. Rodriguez, Chem. Eur. J., 2011, 17, 2266.

23. D. Gravel and M. Lebelle, Can. J. Chem., 1985, 63, 1874.

24. W. G. Dauben and R. A. Bunce, J. Org. Chem., 1983, 48, 4642.

25. T. A. Spencer, H. S. Neel, D. C. Ward and K. L. Williamson, J. Org. Chem., 1966, 31, 434.

26. The crystallographic data for structures $\mathbf{6}$ and $\mathbf{2 0}$ have been deposited with the Cambridge Crystallographic Data centre (CCDC) and are available free of charge under the respective reference numbers (CCDC 1476517) and (CCDC 1485262) at www.ccdc.cam.ac.uk/data_request/cif.

27. E. Harder, W. Damm, J. Maple, C. Wu, M. Rebout, J. Y. Xiang, L. Wang, D. Lupyan, M. K. Dahlgren, J. L. Knight, J. W. Kaus, D. S. Cerutti, G. Krilov, W. L. Jorgensen, R. Abel and R. A. Friesner, J. Chem. Theory Comput., 2016, 12, 281.

28. M. R. Garnsey, D. Lim, J. M. Yost and D. M. Coltart, Org.Lett., 2010, 12, 5234.

29. S. P. Schröder, N. J. Taylor, P. Jackson and V. Franckevicius, Org.Lett., 2013, 15, 3778.

*Corresponding authors: E-mail: c.m.marson@ucl.ac.uk and jean_alexandre@ices.astar.edu.sg 